\title{
Brown Algae Phlorotannins: A Marine Alternative to Break the Oxidative Stress, Inflammation and Cancer Network
}

\author{
Marcelo D. Catarino ${ }^{1} \mathbb{D}$, Sónia J. Amarante ${ }^{1} \mathbb{D}$, Nuno Mateus $^{2} \mathbb{D}$, Artur M. S. Silva ${ }^{1}$ (D) and Susana M. Cardoso ${ }^{1, * \mathbb{D}}$ \\ 1 LAQV-REQUIMTE, Department of Chemistry, University of Aveiro, 3810-193 Aveiro, Portugal; \\ mcatarino@ua.pt (M.D.C.); sonia.amarante@ua.pt (S.J.A.); artur.silva@ua.pt (A.M.S.S.) \\ 2 REQUIMTE/LAQV, Department of Chemistry and Biochemistry, Faculty of Sciences, University of Porto, \\ 4169-007 Porto, Portugal; nbmateus@fc.up.pt \\ * Correspondence: susanacardoso@ua.pt; Tel.: +351-234-370-360; Fax: +351-234-370-084
}

Citation: Catarino, M.D.; Amarante, S.J.; Mateus, N.; Silva, A.M.S.; Cardoso, S.M. Brown Algae Phlorotannins: A Marine Alternative to Break the Oxidative Stress, Inflammation and Cancer Network. Foods 2021, 10, 1478 https://doi.org/10.3390/

foods10071478

Academic Editor: Joana S. Amaral

Received: 31 May 2021

Accepted: 20 June 2021

Published: 25 June 2021

Publisher's Note: MDPI stays neutral with regard to jurisdictional claims in published maps and institutional affiliations.

Copyright: (c) 2021 by the authors. Licensee MDPI, Basel, Switzerland. This article is an open access article distributed under the terms and conditions of the Creative Commons Attribution (CC BY) license (https:// creativecommons.org/licenses/by/ $4.0 /)$

\begin{abstract}
According to the WHO, cancer was responsible for an estimated 9.6 million deaths in 2018 , making it the second global leading cause of death. The main risk factors that lead to the development of this disease include poor behavioral and dietary habits, such as tobacco use, alcohol use and lack of fruit and vegetable intake, or physical inactivity. In turn, it is well known that polyphenols are deeply implicated with the lower rates of cancer in populations that consume high levels of plant derived foods. In this field, phlorotannins have been under the spotlight in recent years since they have shown exceptional bioactive properties, with great interest for application in food and pharmaceutical industries. Among their multiple bioactive properties, phlorotannins have revealed the capacity to interfere with several biochemical mechanisms that regulate oxidative stress, inflammation and tumorigenesis, which are central aspects in the pathogenesis of cancer. This versatility and ability to act either directly or indirectly at different stages and mechanisms of cancer growth make these compounds highly appealing for the development of new therapeutical strategies to address this world scourge. The present manuscript revises relevant studies focusing the effects of phlorotannins to counteract the oxidative stress-inflammation network, emphasizing their potential for application in cancer prevention and/or treatment.
\end{abstract}

Keywords: marine polyphenols; phlorotannins; brown seaweeds; antioxidant; anti-inflammatory; anti-tumor; oxidative stress; inflammation; cancer

\section{Introduction}

Seaweeds have been part of the human nutrition for centuries, particularly among the Far East populations such as China, Japan and Korea, to which seaweed cultivation and processing represent a great source of economic income. In contrast, Western countries have mainly explored seaweeds as a source of phycocolloids and certain fine biochemicals with industrial purposes, although the interest in their direct consumption emerged recently [1]. Marine macroalgae, from the nutritional perspective, are considered a wholesome food, since they contain important key nutrients, including carbohydrates, proteins, lipids and minerals, which are necessary for a heathy and balanced diet [2]. Another important aspect that makes seaweeds so attractive is the ease of their cultivation since they can be produced in cycles with little or no demand of fresh water nor arable land, and high growth rates that exceed those of the terrestrial crops [3]. Apart from their nutritional value, seaweeds are also a great source of many other secondary metabolites with bioactive and health promoting properties, with more than 15,000 novel compounds being reported over the last years [4].

Among them, phlorotannins represent an important group of phenolic compounds, exclusively occurring in brown algae that can form simple structures of 126 Da to very large and complex polymers. Although the biosynthetic pathway of these compounds is still not consensual, it is known that they are formed via $\mathrm{C}-\mathrm{C}$ and/or $\mathrm{C}-\mathrm{O}-\mathrm{C}$ oxidative 
coupling of several monomeric units of phloroglucinol, which in turn is known to be biosynthesized through the acetate-malonate pathway [5]. According to the type of linkage formed between these units and the number of hydroxyl groups, phlorotannins can be classified in four sub-classes, namely phlorethols and fuhalols (ether linkages), fucols (arylaryl linkages), fucophlorethols (aryl-aryl and ether linkages), and eckols and carmalols (dibenzodoxine linkage) [6].

Over the recent years, phlorotannins have drawn much attention from the scientific community due to the numerous biological activities and potential industrial applications they have demonstrated, including antioxidant, anti-inflammatory, anti-obesity and several others [7]. Of these, the antitumor properties of phlorotannins are of great interest since they could represent an interesting therapeutic strategy to fight this condition that is one of the leading causes of death worldwide, second only to heart disease [8]. One of the main peculiarities of these compounds is that in addition to their direct antitumor properties, for example as pro-apoptotic, anti-proliferative, anti-metastatic or antiangiogenic effects, they can also act against tumor development indirectly due to their capacity to inhibit inflammation and oxidative stress, which are well known to play a pivotal role in the pathophysiology of cancer and several other diseases [9-12]. This versatility and capacity to interfere either directly or indirectly in multiple stages of cancer development is what makes phlorotannins so promising for the development of new pharmaceutical products and therapeutical approaches to address this world scourge.

In this context, this review presents an overview of the resourcefulness of phlorotannins to modulate numerous mechanisms underlying oxidative stress and inflammation mechanisms and highlights their contribution for preventing and tackling cancer.

\section{Oxidative Stress, Inflammation and Cancer: How Are They Entangled?}

Oxidative stress can be defined as an imbalance between the production of free radicals and reactive metabolites, commonly known as reactive oxygen and nitrogen species (ROS and RNS), and their elimination by protective mechanisms, referred to as antioxidants [13].

In a normal situation, ROS and RNS have important signaling and physiological functions in human metabolism, which is equipped with several antioxidant mechanisms to maintain their concentration in balanced levels [14]. However, when the homeostasis between antioxidants and reactive species is disturbed, overproduction of ROS and RNS becomes toxic, reacting uncontrollably with endogenous macromolecules including lipids, proteins and DNA, causing serious damage to cells and tissues [15]. These excessive levels of ROS and damages in the cellular structures lead to the activation of distinct kinases and transcription factors such as NF- $\mathrm{KB}$ or AP-1, which are key mediators of the proinflammatory signaling cascade. In turn, when activated, transcription factors promote the expression of pro-inflammatory proteins that include enzymes ((e.g., inducible nitric oxide synthase (iNOS), cyclooxygenase (COX-2) and lipoxygenase (LOX)), cytokines (e.g., tumor necrosis factor- $\alpha$ (TNF- $\alpha$ ), interleukin (IL)-1 $\beta$ and IL-6), chemokines (e.g., monocyte chemoattractant protein 1 (MCP1), macrophage inflammatory protein $1 \alpha(\mathrm{MIP}-1 \alpha)$ and IL-8), adhesion molecules (E-selectin, intercellular adhesion molecule-1 (ICAM-1) and vascular cell adhesion molecule-1 (VCAM-1)) and others, which then stimulate the surrounding cells and recruit others from the immune system [16].

The activated immune cells respond with the generation of more reactive species in an event known as oxidative burst that promote a massive release and accumulation of ROS and RNS in the damaged area and contribute to produce more pro-inflammatory mediators [17]. Until they are contained, all these events result in a self-sustaining cycle where reactive species stimulate the pro-inflammatory chemical mediators that in turn stimulate the production of more reactive species and tissue damage, establishing a perfect environment for the development of a chronic inflammation that leads to several pathological conditions and ultimately cancer.

Cancer is a multistep process defined in three main stages: initiation, promotion and progression [18]. Oxidative stress participates in all the three stages, contributing for the 
introduction of gene mutations and structural alterations of the DNA during the initiation stage, abnormal gene expression, blockage of cell to cell communication and modification of second messenger systems during the promotion stage, leading to an increased cell proliferation or a decreased apoptosis of the mutated cells, and finally contributing for the addition of further DNA alterations during the progression stage [19]. Moreover, it has been demonstrated that ROS are involved in the link between chronic inflammation and cancer, and that an important characteristic of tumor promoters is their ability to recruit inflammatory cells and to stimulate them to generate ROS [20].

One of the key characteristics of tumor cells is their increased survivability and capacity to resist apoptosis, which is a major barrier against tumorigenesis. Once triggered, the apoptotic signaling cascade unfolds in an orchestrated series of steps that culminate in the disruption of cellular membranes, the breakdown of nuclear and cytoplasmic skeleton, extrusion of cytosol, degradation of the chromosomes and fragmentation of the nucleus. In this process, there are essentially two types of components: the regulators, which are responsible for monitoring the extracellular and intracellular environment for conditions of normality or abnormality that influence whether a cell should live or die, and the effectors, which are responsible for the execution phase in which the cell progressively disassembles and gets consumed either by its neighbors or by phagocytic cells [21].

Many of the stimuli that trigger apoptosis converge on the mitochondria, which responds with the release of cytochrome $c$, a potent catalyst of apoptosis. These signals are however controlled by counterbalancing pro- and antiapoptotic members of the B-cell lymphoma 2 (Bcl-2) family of regulatory proteins. The antiapoptotic proteins [such as $\mathrm{Bcl}-2$, B-cell lymphoma extra-large (Bcl- $\left.\mathrm{x}_{\mathrm{L}}\right)$, and others] act by binding and suppressing the proapoptotic proteins (Bcl-2-associated $\mathrm{X}$ protein (Bax) and Bcl-2 homologous antagonist/killer (Bak)) in the mitochondrial outer membrane. When this suppression is lifted, Bax and Bak induce the permeabilization of the outer mitochondrial membrane causing the release of the cytochrome $c$, which in turn will activate the caspase signaling cascade, culminating in the activation of caspase-3, considered the most important of the executioner caspases, and other effector proteins that execute the selective obliteration of subcellular structures, organelles and genome [22].

In order to survive, tumor cells develop a variety of strategies that allow them to escape or limit apoptosis. One of the most common is the loss of function of tumor suppressor protein p53, which has been described as "the guardian of the genome" since it is responsible for controlling the stability of the DNA and upregulate the expression of Bax upon sensing DNA damage, thus inducing apoptosis [23]. In fact, the inactivation of this protein is commonly observed in more than $50 \%$ of human cancers and emerging evidence suggests that the dysfunction of p53 also promotes inflammation and endorses tumor immune evasion, thereby serving as an immunological driver of tumorigenesis [24,25]. In addition, tumors may evade apoptosis by upregulating the expression of antiapoptotic proteins such as $\mathrm{Bcl}-2$ and $\mathrm{Bcl}-\mathrm{x}_{\mathrm{L}}$. Indeed, the overexpression of $\mathrm{Bcl}-2$ has been linked to cancer resistance to chemo- and immunotherapy [26]. Other tumor evasion strategies include overexpression of survival signals, downregulation of multiple proapoptotic factors or short-circuiting the extrinsic ligand-induced death pathway. The variety of apoptosisevading mechanisms presumably reflects the different apoptosis-inducing stimuli that tumor cell populations face and overcome during their development and evolution to the malignant state [27].

\section{The Contribution of Phlorotannins}

\subsection{Role in Oxidative Stress and Inflammation}

As phenolic compounds, the most characteristic biological property of phlorotannins is their antioxidant activity, which has been extensively explored and is encompassed by a large number of studies in literature contemplating numerous phlorotannin-rich extracts or isolated phlorotannins from multiple algal species and geographic origins, obtained with different extraction procedures and evaluated by a multitude of antioxidant assays 
(Table 1). Not only these compounds are capable of chelating metals and scavenging free radicals in the intracellular environment $[9,28,29]$, but they also inhibit pro-oxidant enzymes and redox-sensitive mediators [30], and increase auto-antioxidant defenses through positive regulation of phase II detoxifying enzymes [31-33]. The most studied parameter for measuring the antioxidant activity is the formation of ROS. This is usually evaluated by the scavenging activities of 1,1-diphenyl-1,2-picrylhydrazyl (DPPH), 2,2'-azinobis(3ethylbenzothiazoline-6-sulphonic acid $\left(\mathrm{ABTS}^{+}\right)$, peroxyl $\left(\mathrm{RCOO}^{\bullet}\right)$, alkyl, $\mathrm{HO}^{\bullet}$, and $\mathrm{O}_{2}^{\bullet-}$ assays and a decrease of ROS in the presence of phlorotannins has been consensually observed [28,32,34-38]. In many cases, their effects are even stronger when compared to well-known antioxidant compounds, such as ascorbic acid, $\alpha$-tocopherol, butylated hydroxytoluene (BHT) and others. For instance, both soluble and membrane bound phlorotannin extracts from $A$. nodosum were shown to exert markedly higher $\mathrm{DPPH}^{\bullet}$ scavenging activity $\left(\mathrm{IC}_{50}=6.3-7.7 \mu \mathrm{g} / \mathrm{mL}\right)$ than $\mathrm{BHT}\left(\mathrm{IC}_{50}=51 \mu \mathrm{g} / \mathrm{mL}\right)$, and those from F. vesiculosus $\left(\mathrm{IC}_{50}=3.8-4.7 \mu \mathrm{g} / \mathrm{mL}\right)$ were even stronger than ascorbic acid $\left(\mathrm{IC}_{50}=6.3 \mu \mathrm{g} / \mathrm{mL}\right)$ [39]. Likewise, a phlorotannin purified extract from $F$. vesiculosus, displayed a DPPH ${ }^{\bullet}$ scavenging activity better than $\alpha$-tocopherol $\left(\mathrm{IC}_{50}=3.76\right.$ against $\left.5.93 \mu \mathrm{g} / \mathrm{mL}\right)$ and comparable to that of BHT $\left(\mathrm{IC}_{50}=3.28 \mu \mathrm{g} / \mathrm{mL}\right)$ [40]. In a different study, the phlorotannin fraction purified from Sargassum ringgoldianum showed approximately five times stronger $\mathrm{O}_{2}{ }^{\bullet-}$ scavenging activity than catechin $\left(\mathrm{IC}_{50}=1.0\right.$ against $\left.4.6 \mu \mathrm{g} / \mathrm{mL}\right)$ [41].

Some isolated compounds from Ecklonia stolonifera, namely eckstolonol, dieckol, phlorofucofuroeckol $\mathrm{A}$ also revealed lower $\mathrm{IC}_{50}$ values $(8.8,6.2$ and $4.7 \mu \mathrm{M}$, respectively) than ascorbic acid $(10.3 \mu \mathrm{M})$ on $\mathrm{DPPH}^{\bullet}$ scavenging assay, thus evidencing remarkable antioxidant activity [38]. In turn eckol, phlorofucofuroeckol A, dieckol and 8,8'-bieckol isolated from Eisenia bicyclis, Ecklonia cava and Ecklonia kurome, were twice more effective scavengers of $\mathrm{DPPH}^{\bullet}\left(\mathrm{IC}_{50}=26,12,13\right.$ and $15 \mu \mathrm{M}$, respectively) than catechin, ascorbic acid and $\alpha$-tocopherol $\left(\mathrm{IC}_{50}=32,30\right.$ and $52 \mu \mathrm{M}$, respectively). The same tendency was observed for the $\mathrm{O}_{2}{ }^{\bullet-}$ scavenging in which these compounds exhibited considerably lower $\mathrm{IC}_{50}$ values $(10.7,8.4,7.6$ and $6.5 \mu \mathrm{M}$, respectively) than resveratrol, ascorbic acid or $\alpha$-tocopherol $\left(\mathrm{IC}_{50}=21,16\right.$ and $12 \mu \mathrm{M}$, respectively) [42].

Promising results have been observed in different cellular systems of oxidative stress as well, with several authors reporting a decrease of the intracellular ROS on cells treated either with phlorotannin-rich extracts or pure compounds [40,43-49]. Decrease of the DNA oxidative degradation in oxidative stress-induced cells has been described for phlorotannin extracts from species such as F. vesiculosus, F. serratus or A. nodosum [50-53], and pure compounds including phloroglucinol, eckol, dieckol and 2,7'-phloroglucinol-6,6'-bieckol isolated from E. cava $[9,54,55]$. Significant dose-dependent inhibitions of myeloperoxidase (MPO) activity, an enzyme that produces $\mathrm{HOCl}$ from $\mathrm{H}_{2} \mathrm{O}_{2}$ and $\mathrm{Cl}^{-}$, were also observed in HL-60 cells treated with phlorofucofuroeckol A, diphlororethohydroxycarmalol, 7-phloroeckol and 6,6'-bieckol prior to a pro-oxidant stimulus [34,56]. In addition to the cellular models, in vivo experiments have shown that phlorotannin extracts from Lessonia vadosa and Macrocystis pyrifera were able to prevent UV-B-induced ROS and malformations in zebrafish [57]. Likewise, compounds such as dieckol, phlorofucofuroeckol A 6,6'-bieckol, phloroglucinol, eckol, eckstolonol and triphloroethol A, all isolated from E. cava, were reported as effective inhibitors of intracellular ROS, lipid peroxidation and DNA damage either in ethanol, 2,2'-azobis-2-methyl-propanimidamide dihydrochloride (AAPH), high glucose or UV-B-exposed zebrafish [28,35,58,59]. 
Table 1. Selected in vivo or ex vivo studies of the antioxidant activity of phlorotannins and phlorotannins extracts from brown algae.

\begin{tabular}{|c|c|c|c|c|}
\hline Extract/Compound & Model & Conditions & Effect & Ref. \\
\hline \multicolumn{5}{|c|}{ Sargassum kjellmanianum } \\
\hline $\begin{array}{l}\text { EtOH } 85 \% \rightarrow \text { Fract. } \\
\mathrm{CHCl}_{3} \rightarrow \mathrm{PE} \rightarrow \text { cellulose } \\
\text { column } \rightarrow \text { HMW phlorotannins }\end{array}$ & $\begin{array}{l}\mathrm{CCl}_{4} \text { or } \mathrm{FeSO}_{4}-\mathrm{V}_{\mathrm{C}} \text {-induced liver homogenate } \\
\text { in Kumming mice }\end{array}$ & $\begin{array}{l}\text { Oral administration with } 5.0 \mathrm{~g} / \mathrm{kg} \text { before } \\
\text { obtaining liver homogenate }\end{array}$ & $\downarrow$ MDA, lipid peroxidation and swelling & {$[60]$} \\
\hline \multicolumn{5}{|c|}{ Sargassum pallidum } \\
\hline Ac $70 \% \rightarrow$ Fract. DCM $\rightarrow$ EtOAc & Wistar rats with $\mathrm{CCl}_{4}$-induced hepatic injury & $\begin{array}{l}\text { Oral administration of } 100 \mathrm{mg} / \mathrm{kg} \text { for } 1 \text { week } \\
\text { after } \mathrm{CCl}_{4} \text { injection }\end{array}$ & $\downarrow \mathrm{MDA} ; \uparrow \mathrm{GSH}$ and SOD & {$[61]$} \\
\hline \multicolumn{5}{|c|}{ Fucus vesiculosus } \\
\hline $\begin{array}{l}\text { Ext. 1: EtOH } 30 \%-35 \% \\
\text { Ext. 2: EtOH } 50 \%-70 \%\end{array}$ & Sprague-dawley rats & $\begin{array}{l}\text { Oral administration of } 200 \mathrm{mg} / \mathrm{kg} / \text { day } \\
\text { for } 4 \text { weeks }\end{array}$ & $\begin{array}{l}\uparrow \text { antioxidant defenses, PON- } 1 \text { and } \downarrow \text { MDA } \\
\text { (in plasm) and } \uparrow \text { SOD (in rats' erythrocytes) }\end{array}$ & {$[43]$} \\
\hline \multicolumn{5}{|c|}{ Lessonia vadosa } \\
\hline $\mathrm{Ac} \rightarrow \mathrm{Ac} \mathbf{7 0} \%$ & UVB-induced zebrafish & $\begin{array}{l}40 \mu \mathrm{g} / \mathrm{mL} \text { PGE prior to irradiation } \\
\left(0.15 \mathrm{~mW} / \mathrm{cm}^{2}\right)\end{array}$ & $\downarrow$ ROS and malformations & [57] \\
\hline \multicolumn{5}{|c|}{ Macrocystis pyrifera } \\
\hline \multicolumn{5}{|c|}{ Ascophyllum nodosum } \\
\hline $\begin{array}{l}\text { EtOH } 60 \% \rightarrow \text { Fract. tangential } \\
\text { flow ultrafiltration }\end{array}$ & Human trials & $\begin{array}{l}\text { Oral administration of a food-grade capsule } \\
\text { containing } 100 \mathrm{mg} \text { of polyphenols for } 8 \text { weeks }\end{array}$ & $\downarrow$ DNA damage in obese subjects & {$[62]$} \\
\hline \multicolumn{5}{|c|}{ Himanthalia enlogata } \\
\hline $\begin{array}{l}\text { Restructured pork with } 5 \% \\
\text { seaweed powder }\end{array}$ & Hypercholesterolaemia-induced Wistar rats & Feeding ad libitum over 5 weeks & $\begin{array}{l}\uparrow \text { CYP7A1, GR and SOD levels in } \\
\text { liver homegenates }\end{array}$ & [63] \\
\hline \multicolumn{5}{|c|}{ Laminaria japonica } \\
\hline Aqueous extract & STZ-induced diabetes in Sprague-Dawley rats & $\begin{array}{l}\text { Oral gavage of } 100 \mathrm{mg} / \mathrm{kg} / \mathrm{d} \text { for } 5 \text { days prior to } \\
\text { STZ injection }(55 \mathrm{mg} / \mathrm{kg})\end{array}$ & $\downarrow$ lipid peroxidation, XO; $\uparrow$ GSH, GPx and GR & {$[64]$} \\
\hline \multicolumn{5}{|c|}{ Isolated compounds } \\
\hline Dieckol from Ecklonia stolonifera & ICR mice & Oral administration of $100 \mathrm{mg} / \mathrm{kg} / \mathrm{d}$ for 4 days & $\uparrow \mathrm{HO}-1$ & [32] \\
\hline 6,6-bieckol & High glucose-induced zebrafish & $20 \mu \mathrm{M} 16$ prior to glucose stimulation & $\downarrow$ ROS & [35] \\
\hline
\end{tabular}


Table 1. Cont.

\begin{tabular}{|c|c|c|c|c|}
\hline Extract/Compound & Model & Conditions & Effect & Ref. \\
\hline \multirow{7}{*}{ Dieckol from Ecklonia cava } & $\begin{array}{l}\gamma \text {-radiation-induced hepatocyte cells isolated } \\
\text { from Wistar rats }\end{array}$ & 5-20 $\mu \mathrm{M} 1 \mathrm{~h}$ prior to irradiation (8 Gy/min) & $\begin{array}{l}\downarrow \text { lipid peroxidation, DNA damage; } \\
\uparrow \text { SOD, CAT, GSH and GPx }\end{array}$ & [65] \\
\hline & C57BL/KsJ-db/db mice & 10 and $2010 \mathrm{mg} / \mathrm{kg} / \mathrm{d}$ over 14 days & $\downarrow$ lipid peroxidation; $\uparrow$ SOD, GPx and CAT & [33] \\
\hline & $\mathrm{CCl}_{4}$-induced hepatic injury in ICR mice & $\begin{array}{l}\text { Oral administration of } 5 \mathrm{mg} / \mathrm{kg} / \mathrm{d} 6 \text { days prior } \\
\text { to } \mathrm{CCl}_{4} \text { administration }(0.5 \mathrm{mg} / \mathrm{kg})\end{array}$ & $\downarrow \mathrm{MDA} ; \uparrow \mathrm{SOD}, \mathrm{GPx}$ and CAT & [66] \\
\hline & AAPH-induced zebrafish & $50 \mu \mathrm{M} 1 \mathrm{~h}$ prior to AAPH exposure $(25 \mathrm{mM})$ & $\downarrow$ ROS, lipid peroxidation and cell death & [28] \\
\hline & High glucose-induced zebrafish & $20 \mu \mathrm{M} 16 \mathrm{~h}$ prior to glucose exposure $(50-300 \mathrm{mM})$ & $\downarrow$ ROS cell death and lipid peroxidation & [35] \\
\hline & EtOH-induced zebrafish & 10 and $20 \mu \mathrm{M} 1 \mathrm{~h}$ prior to ethanol exposure $(0.5 \%)$ & $\downarrow$ ROS, lipid peroxidation and cell death & [58] \\
\hline & UVB-induced zebrafish & $50 \mu \mathrm{M} 1 \mathrm{~h}$ prior to irradiation $(50 \mathrm{~mJ} / \mathrm{cm})$ & $\downarrow$ ROS and cell death & [59] \\
\hline \multirow{2}{*}{ Eckol from Ecklonia cava } & AAPH-induced zebrafish & $50 \mu \mathrm{M} 1 \mathrm{~h}$ prior to $\mathrm{AAPH}$ exposure $(25 \mathrm{mM})$ & $\downarrow$ ROS, lipid peroxidation and cell death & [28] \\
\hline & EtOH-induced zebrafish & 10 and $20 \mu \mathrm{M} 1 \mathrm{~h}$ prior to ethanol exposure $(0.5 \%)$ & $\downarrow$ ROS, lipid peroxidation and cell death & [58] \\
\hline Eckol commercial & $\mathrm{CCl}_{4}$-induced hepatic injury in Kumming mice & $\begin{array}{l}\text { Oral administration of } 0.5 \text { and } 1 \mathrm{mg} / \mathrm{kg} / \mathrm{d} 7 \text { days } \\
\text { prior to } \mathrm{CCl}_{4} \text { injection }(0.5 \%)\end{array}$ & $\downarrow \mathrm{MDA} ; \uparrow \mathrm{SOD}, \mathrm{GPx}$ and GSH & [67] \\
\hline Eckstolonol from Ecklonia cava & AAPH-induced zebrafish & $50 \mu \mathrm{M} 1 \mathrm{~h}$ prior to $\mathrm{AAPH}$ exposure $(25 \mathrm{mM})$ & $\downarrow$ ROS, lipid peroxidation and cell death & [28] \\
\hline \multirow{2}{*}{$\begin{array}{l}\text { Phlorofucofuroeckol A from } \\
\text { Ecklonia cava }\end{array}$} & High glucose-induced zebrafish & $\begin{array}{l}20 \mu \mathrm{M} 16 \mathrm{~h} \text { prior to glucose exposure } \\
(50-300 \mathrm{mM})\end{array}$ & $\downarrow$ ROS & [35] \\
\hline & AAPH- induced zebrafish & $50 \mu \mathrm{M} 1 \mathrm{~h}$ prior to $\mathrm{AAPH}$ exposure $(25 \mathrm{mM})$ & $\downarrow$ ROS and cell death & {$[47]$} \\
\hline \multirow{2}{*}{ Phloroglucinol from Ecklonia cava } & AAPH-induced zebrafish & $50 \mu \mathrm{M} 1 \mathrm{~h}$ prior to AAPH exposure $(25 \mathrm{mM})$ & $\downarrow$ ROS, lipid peroxidation and cell death & [28] \\
\hline & EtOH-induced zebrafish & 10 and $20 \mu \mathrm{M} 1 \mathrm{~h}$ prior to ethanol exposure $(0.5 \%)$ & $\downarrow$ ROS, lipid peroxidation and cell death & [58] \\
\hline Phloroglucinol commercial & CYP-induced in Sprague-Dawley rat & $\begin{array}{l}15 \text { and } 30 \mathrm{mg} / \mathrm{kg} / \mathrm{d} \text { i.p. over } 7+75 \mathrm{mg} / \mathrm{kg} \text { of } \\
\text { CYP i.p. at day 1, } 4 \text { and } 7\end{array}$ & $\downarrow \mathrm{MPO}$ and $\uparrow \mathrm{CAT}$ & [30] \\
\hline Triphloroethol A from Ecklonia cava & AAPH-induced zebrafish & $50 \mu \mathrm{M} 1 \mathrm{~h}$ prior to AAPH exposure $(25 \mathrm{mM})$ & $\downarrow$ ROS, lipid peroxidation and cell death & [28] \\
\hline
\end{tabular}

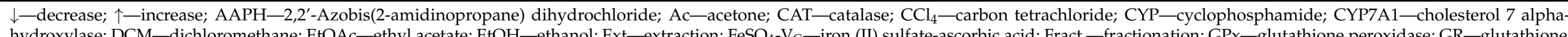

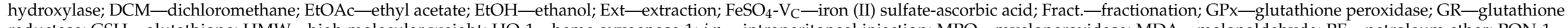

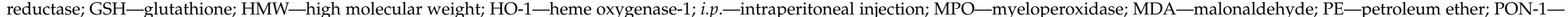
paraoxonase-1; ROS—reactive oxygen species; SOD—superoxide dismutase; STZ—-streptozotocin; UVB—ultraviolet-B; XO—xanthine oxidase. 
In a different model, the prolonged consumption of high molecular weight phlorotannins from Sargassum kjellmanianum by Kunming mice $(5.0 \mathrm{~g} / \mathrm{kg}$ body weight/day over 30 days) was shown to significantly protect the liver against the lipid peroxidation induced either by $\mathrm{CCl}_{4}$ or $\mathrm{FeSO}_{4}-\mathrm{V}_{\mathrm{C}}$ [60]. Notably, in a randomized controlled trial, modest improvements in the DNA damage were observed in obese people after eight weeks of consuming $400 \mathrm{mg}$ /day of an A. nodosum phenolic-rich extract [62].

Apart from the direct antioxidant properties, the capacity of phlorotannins to boost the auto-antioxidant defenses is a subject that has also shown promising results. For instance, superoxide dismutase (SOD) and catalase (CAT), which are two important detoxifying enzymes that are usually downregulated in cells under oxidative stress, were shown to be increased on different cell lines treated either with phlorotannin-rich extracts (from F. vesiculosus, F. serratus, Pelvetia canaliculata and A. nodosum) [43,51,52] or isolated phlorotannin compounds including phloroglucinol, eckol, eckstolonol, dieckol and triphlorethol A [31,32,48,49,68-70]. Likewise, glutathione (GSH), GSH peroxidase (GPx), GSH reductase (GR) and GSH-S-transferase (GST), which are crucial players in the neutralization of ROS and intimately associated to the maintenance of the redox balance in living organisms, were reported in multiple studies to be upregulated in response to the treatment of $A$. nodosum, H. elongata, F. serratus, F. vesiculosus, Pelvetia canaliculata, E. cava and Eisenia bicyclis phlorotannin extracts $[45,50,51,71]$ as well as to phloroglucinol, triphlorethol A, eckol, phlorofucofuroeckol A, 7-phloroeckol and 6,6'-bieckol [31,34,65,70,72]. As reported by the authors, it is possible that phlorotannins may interfere with the transcriptional activity of the nuclear factor erythroid 2-related factor 2 (Nrf2), which is the major regulator of the phase II detoxifying enzymes [73]. Indeed, dieckol was demonstrated to enhance the levels of detoxifying enzymes heme oxygenase- $1(\mathrm{HO}-1), \mathrm{NAD}(\mathrm{P}) \mathrm{H}$ :quinine oxidoreductase 1 (NQO1) and GST via upregulation of the Nrf2 transcriptional activity in $\mathrm{H}_{2} \mathrm{O}_{2}$-induced HepG2 cells [32]. Similar results were described for eckol, which was equally capable of stimulating the expression of HO- 1 in V79-4 cells [74] and $\mathrm{H}_{2} \mathrm{O}_{2}$-induced HepG2 cells [31], both through activation of the nuclear translocation and transcriptional activity of Nrf2.

The phlorotannins capacity to upregulate the auto-antioxidant defenses has even been confirmed in vivo. According to Moreira et al. [63], the incorporation of H. elongata in restructured meat given to hypercholesterolemic rats over 35 days significantly contributed for the restoration of the levels of GR and $\mathrm{Cu}, \mathrm{Zn}$-SOD in their livers. In a different approach, the administration of $55 \mathrm{mg} / \mathrm{kg} /$ day of L. japonica extract to streptozotocin-induced diabetes in Sprague-Dawley rats over five days not only significantly reduced the expression of XO, but also increased the levels of GSH, GPx and GR in the liver of the treated animals [64]. Similarly, the prolonged oral administration of Sargassum pallidum to Wistar rats with $\mathrm{CCl}_{4}$-induced hepatic injury was shown to remarkably increase both GSH and SOD levels in the livers of the treated animals [61]. Upregulated SOD, GPx, GSH and CAT have also been reported in injured liver tissues of mice treated either with eckol [67] or dieckol $[33,66]$. Phloroglucinol was even demonstrated to ameliorate the midbrain lesions in rats with 6-hydroxydopamine-induced Parkinson's disease, most likely through restoration of the reduced levels of CAT and GPx via stimulation of Nrf2 activity [75].

In addition to their antioxidant properties, phlorotannins are also closely related to numerous inflammatory events, being capable of inhibiting the expression of proinflammatory cytokines, regulate the expression and/or activity of important enzymes and even interfere with the transcriptional regulation (Table 2), making them promising therapeutic agents for mitigating inflammation and inflammatory-related diseases, which includes cancer [76-78].

Due to their wide distribution and ecological importance, seaweeds from the genus Eisenia and Ecklonia are perhaps the most studied in this field. The majority of the phlorotannins obtained from these seaweeds were proven of being able to inhibit the expression of cellular adhesion molecules, like ICAM- 1 and VCAM- 1 and cytokines, namely TNF- $\alpha$, IL$1 \beta$ and IL-6, in several cells of the immune system [54,79-82]. Likewise, the release of NO• and $\mathrm{PG}_{2}$, as well as the expression of enzymes responsible for their synthesis, i.e., iNOS and 
COX-2, respectively, were found reduced in cells treated with E. cava, E. stolonifera and E. arborea extracts [83-87], or phlorotannin compounds from them isolated including phloroglucinol, dieckol, fucofuroeckol A, 6,6'-bieckol and phlorofucofuroeckol A [38,80-82,88,89]. Other seaweeds have proven their capability of inhibiting multiple pro-inflammatory markers as well. Barbosa et al. [90] recently demonstrated that phlorotannin-purified extracts from several species of Fucus, namely F. vesiculosus, F. guiryi, F. spiralis and F. serratus, dose-dependently inhibited the LPS-induced NO• secretion in Raw 264.7 macrophages, which is in line with previous studies from Zaragozá et al. [43], who also described a dose-dependent inhibition of $\mathrm{NO}^{\bullet}$ production on PMA-stimulated macrophages after being treated with a phlorotannin-rich F. vesiculosus ethanol extract. Likewise, phlorotannin extracts of several species of Sargassum including $S$. horneri, S. sagamianum and S. patens were shown to affect the expression of $\mathrm{NO}^{\bullet}, \mathrm{PG}_{2}, \mathrm{IL}-1 \beta, \mathrm{IL}-6$ and TNF- $\alpha$ in LPS-stimulated Raw 264.7 macrophages [91-93], whereas in HaCaT cells exposed to UV-B radiation, the addition of $S$. fulvellum ethanolic extract prevented the expression of $\mathrm{NO}^{\bullet}, \mathrm{PG}_{2}, \mathrm{TNF}-\alpha$, COX-2 and iNOS [94]. In turn, the treatment of LPS-stimulated Raw 264.7 macrophages with different purified fractions of a polyphenol extract from Macrocystis pyrifera not only exerted inhibitory effects towards NO ${ }^{\bullet}, \mathrm{TNF}-\alpha$ and iNOS but also stimulated the expression of IL-10 which is an important anti-inflammatory cytokine responsible for the suppression of cytokines secretion [87].

Evidence have shown that the anti-inflammatory capacity of these compounds is much likely to be related with their modulatory effects on important transcription factors that mediate the inflammatory signaling cascade. In fact, it has been proven that the addition of E. cava ethanolic extract to LPS-stimulated Raw 264.7 macrophages dosedependently diminished the levels of TNF- $\alpha$, IL-1 $\beta$, IL-6, iNOS, COX-2, NO• and PG 2 via inhibition of the nuclear NF- $\mathrm{kB}$ translocation [83]. Notably, the E. cava ethanolic extract ability to inhibit NF- $\mathrm{KB}$ nuclear translocation and binding to DNA in LPS-stimulated BV2 microglia cells was caused by the inhibition of both I $\mathrm{B} \alpha$ degradation and mitogenactivated protein kinase (MAPK) pathway, which also contributes for the regulation of proinflammatory cytokines biosynthesis [84]. Yayeh et al. [95] reported that the inactivation of LPS-induced NF- $\mathrm{BB}$ transcriptional activity in dieckol-treated Raw 264.7 macrophages occurs via inhibition of the phosphorylation of NF- $\mathrm{B}$ p 65 subunit and its upstream kinases namely PI3K, Akt, IKK- $\alpha / \beta$ and $I \kappa B \alpha$, which is an inhibitory route very similar to that described for phlorofucofuroeckol A in LPS-stimulated Raw 264.7 cells [96] and 6,6' bieckol in LPS-stimulated BV2 cells [97]. In phloroglucinol-treated LPS-stimulated Raw 264.7 macrophages, the inactivation NF- $\mathrm{BB}$ occurred via a different path, through inhibition of the upstream kinases IKK and NF-KB inducing kinase (NIK) [54]. 
Table 2. Selected in vivo or ex vivo studies of the anti-inflammatory activity of phlorotannins extracts and isolated phlorotannins from brown algae.

\begin{tabular}{|c|c|c|c|c|}
\hline Extract/Compound & Model & Conditions & Effect & Ref. \\
\hline \multicolumn{5}{|c|}{ Cystoseira sedoides } \\
\hline $\mathrm{EtOH} 50 \% \rightarrow$ Fract. PE $\rightarrow$ DCM $\rightarrow$ EtOAc & $\begin{array}{l}\text { Model 1-XYL-induced mice ear edema } \\
\text { Models 2-Carrageenan-induced paw edema in } \\
\text { Wistar rats }\end{array}$ & $\begin{array}{l}\text { Model } 1-50 \text { and } 100 \mathrm{mg} \text { EtOAc } / \mathrm{kg} \text { s.c. } 30 \mathrm{~min} \\
\text { prior to XYL application } \\
\text { Model } 2-50 \text { and } 100 \mathrm{mg} \text { EtOAc/ } / \mathrm{kg} \text { i.p. } 30 \mathrm{~min} \\
\text { prior to carrageenan application }\end{array}$ & $\begin{array}{l}\text { Model } 1-\downarrow \text { swelling up to } 83 \% \\
\text { Model } 2-\downarrow \text { swelling up to } 81 \%\end{array}$ & [98] \\
\hline \multicolumn{5}{|c|}{ Cladostephus spongiosis } \\
\hline $\mathrm{EtOH} 50 \% \rightarrow$ Fract. $\mathrm{PE} \rightarrow \mathrm{DCM} \rightarrow$ EtOAc & $\begin{array}{l}\text { Model 1-XYL-induced mice ear edema } \\
\text { Models 2-Carrageenan-induced paw edema in } \\
\text { Wistar rats }\end{array}$ & $\begin{array}{l}\text { Model } 1-50 \text { and } 100 \mathrm{mg} \text { EtOAc } / \mathrm{kg} \text { s.c. } 30 \mathrm{~min} \\
\text { prior to XYL } \\
\text { Model } 2-50 \text { and } 100 \mathrm{mg} \text { EtOAc/ } / \mathrm{kg} \text { i.p. } 30 \mathrm{~min} \\
\text { prior to carrageenan }\end{array}$ & $\begin{array}{l}\text { Model } 1-\downarrow \text { swelling up to } 69 \% \\
\text { Model } 2-\downarrow \text { swelling up to } 71 \%\end{array}$ & [98] \\
\hline \multicolumn{5}{|c|}{ Padina pavonica } \\
\hline $\mathrm{EtOH} 50 \% \rightarrow$ Fract. $\mathrm{PE} \rightarrow \mathrm{DCM} \rightarrow$ EtOAc & Carrageenan-induced paw edema in Wistar rats & $\begin{array}{l}50 \text { and } 100 \mathrm{mg} \text { EtOAc/ } \mathrm{kg} \text { i.p. } 30 \mathrm{~min} \text { prior } \\
\text { to carrageenan }\end{array}$ & $\downarrow$ swelling up to $58 \%$ & [98] \\
\hline \multicolumn{5}{|c|}{ Sargassum horneri } \\
\hline EtOH 70\% & $\begin{array}{l}\text { OVA + PM-induced lung inflammation in } \\
\text { BALB/c mice }\end{array}$ & $\begin{array}{l}200 \text { and } 400 \mathrm{mg} \text { extract } / \mathrm{kg} \text { orally administered } \\
\text { before PM }\end{array}$ & $\begin{array}{l}\downarrow \text { iNOS and COX-2, IL-1 } \beta, \text { IL-6, } \\
\text { TNF- } \alpha, \text { pERK } 1 / 2, \text { p-p38-MAPK } \\
\text { and p-JNK; } \uparrow \text { HO- } 1 \text { and Nrf- } 2\end{array}$ & [99] \\
\hline \multicolumn{5}{|c|}{ Sargassum sagamianum } \\
\hline EtOH $80 \%$ & Ear edema in ICR mice & $0-100 \mu \mathrm{g} / \mathrm{mL}$ of extract $+1 \mu \mathrm{g} / \mathrm{mL}$ LPS & $\downarrow$ swelling & [92] \\
\hline \multicolumn{5}{|c|}{ Sargassum fulvellum } \\
\hline $\mathrm{EtOH} 95 \% \rightarrow$ fract $\mathrm{H}_{2} \mathrm{O} \rightarrow$ EtOAc $\rightarrow n$-But & UVB-induced BALB/c mice & $\begin{array}{l}3 \text { and } 10 \mu \mathrm{g} \text { topically applied in the back } 30 \mathrm{~min} \\
\text { prior to irradiation }\end{array}$ & $\begin{array}{l}\text { EtOAc fraction } \downarrow \mathrm{NO}^{\bullet}, \mathrm{PGE}_{2} \\
\text { TNF- } \alpha, \text { COX- } 2 \text { and iNOS }\end{array}$ & [94] \\
\hline \multicolumn{5}{|c|}{ Myagropsis myagroides } \\
\hline EtOH 96\% & PMA-induced ear edema in mice & $\begin{array}{l}90 \mu \mathrm{g} \text { topically administered } 1 \mathrm{~h} \text { prior to } \\
\text { PMA injection }\end{array}$ & $\downarrow$ swelling in $67 \%$ & {$[100$} \\
\hline \multicolumn{5}{|c|}{ Ecklonia cava } \\
\hline $\mathrm{EtOH} 70 \%$ & Periodontitis-induced Sprague-Dawley rats & $100-400 \mu \mathrm{g}$ extract $/ \mathrm{kg} /$ day for 8 weeks & $\begin{array}{l}\downarrow \text { gene expression IL-1 } 1 \beta, \text { MMP-2 } \\
\text { and }-9 \text { and RANKL/OPG ratio }\end{array}$ & {$[83]$} \\
\hline
\end{tabular}


Table 2. Cont.

\begin{tabular}{|c|c|c|c|c|}
\hline Extract/Compound & Model & Conditions & Effect & Ref. \\
\hline $\mathrm{EtOH} 30 \% \rightarrow \mathrm{EtOH} 95 \%$ & LPS-induced septic shock in C57BL/6 mice & $\begin{array}{l}10-100 \mathrm{mg} / \mathrm{kg} / \mathrm{d} \text { orally administered over } 7 \text { days } \\
\text { before i.p. of LPS }(25 \mathrm{mg} / \mathrm{kg})\end{array}$ & $\begin{array}{l}\downarrow \mathrm{NO}^{\bullet}, \mathrm{PGE}_{2}, \text { iNOS, COX-2, IL-6, } \\
\text { TNF- } \alpha, \mathrm{HMGB}-1 \text {, and p-NIK, } \\
\text { p-TAK1, p-IKK, p-IkB } \alpha, \text { NF-kB-p50 } \\
\text { and -p65; } \uparrow \text { HO-1 and Nrf-2 }\end{array}$ & [101] \\
\hline \multicolumn{5}{|c|}{ Ascophyllum nodosum } \\
\hline $\begin{array}{l}\text { EtOH } 60 \% \rightarrow \text { fract } \rightarrow \text { food-grade capsule } \\
(101.89 \mathrm{mg} \text { TPC })\end{array}$ & LPS-induced Human blood ex vivo & $\begin{array}{l}\text { Oral administration of a single capsule prior to } \\
\text { blood collection }\end{array}$ & $\downarrow$ IL-6 & [102] \\
\hline \multicolumn{5}{|c|}{ Isolated compounds } \\
\hline \multirow{2}{*}{ 6,6'-Bieckol from Eisenia arborea } & AA, TPA, OXA-induced ear edema in ICR mice & $\begin{array}{l}\text { Topical application }(15 \mathrm{nmol} / \mu \mathrm{L}) \text { with } \\
\text { each sensitizer }\end{array}$ & $\begin{array}{l}\downarrow \text { swelling in } 62 \%, 36 \% \text { and } \\
59 \% \text {, respectively }\end{array}$ & [103] \\
\hline & AA, TPA, OXA-induced ear edema & $\begin{array}{l}\text { Oral gavage of } 75 \mathrm{nmol}, 18 \mathrm{~h} \text { prior to } \\
\text { each sensitizer }\end{array}$ & $\begin{array}{l}\downarrow \text { swelling } 42 \%, 34 \% \text { and } \\
18 \% \text {, respectively }\end{array}$ & [104] \\
\hline 6,6'-bieckol from Myagropsis myagroides & PMA-induced ear edema in mice & $\begin{array}{l}30 \mu \mathrm{g} \text { topically administered, } 1 \mathrm{~h} \text { prior to } \\
\text { PMA injection }\end{array}$ & $\downarrow$ swelling in $64 \%$ & [100] \\
\hline \multirow{2}{*}{ 6,8'-bieckol from Eisenia arborea } & AA, TPA, OXA-induced ear edema in ICR mice & $\begin{array}{l}\text { Topical application }(15 \mathrm{nmol} / \mu \mathrm{L}) \text { with } \\
\text { each sensitizer }\end{array}$ & $\begin{array}{l}\downarrow \text { swelling in } 56 \%, 66 \% \text { and } \\
78 \% \text {, respectively }\end{array}$ & [103] \\
\hline & AA, TPA, OXA-induced ear edema & $\begin{array}{l}\text { Oral gavage of } 75 \mathrm{nmol}, 18 \mathrm{~h} \text { prior to } \\
\text { each sensitizer }\end{array}$ & $\begin{array}{l}\downarrow \text { swelling } 40 \%, 49 \% \text { and } \\
78 \% \text {, respectively }\end{array}$ & [104] \\
\hline \multirow{2}{*}{ 8,8'-Bieckol from Eisenia arborea } & AA, TPA, OXA-induced ear edema in ICR mice & $\begin{array}{l}\text { Topical application }(0.01-0.1 \mathrm{mg} / \mathrm{mL}) \text { with } \\
\text { each sensitizer }\end{array}$ & $\begin{array}{l}\downarrow \text { swelling up to } 80 \%, 49 \% \text { and } \\
71 \% \text {, respectively }\end{array}$ & [105] \\
\hline & AA, TPA, OXA-induced ear edema & $\begin{array}{l}\text { Oral gavage of } 75 \mathrm{nmol}, 18 \mathrm{~h} \text { prior to } \\
\text { each sensitizer }\end{array}$ & $\begin{array}{l}\downarrow \text { swelling } 21 \%, 32 \% \text { and } \\
32 \% \text {, respectively }\end{array}$ & [104] \\
\hline Dieckol from Eisenia bicyclis & Acetic acid-induced ICR mice & $20 \mu \mathrm{M}, 6 \mathrm{~h}$ prior to i.p. $0.7 \%$ acetic acid & $\begin{array}{l}\downarrow \text { CAMs and adhesion and } \\
\text { migration of leucocytes }\end{array}$ & {$[79]$} \\
\hline \multirow{4}{*}{ Dieckol from Ecklonia cava } & $\gamma$-radiation induced hepatocytes from Wistar rats & 5-20 $\mu \mathrm{M} 1 \mathrm{~h}$ prior to irradiation (8 Gy/min) & $\downarrow$ NF-kB and COX-2 & [65] \\
\hline & $\mathrm{CoCl}_{2}$-induced hepatocytes from ICR mice & $100 \mu \mathrm{M} 30 \mathrm{~min}$ prior to $\mathrm{CoCl}_{2}$ stimulation $(500 \mu \mathrm{M})$ & $\downarrow$ COX-2 and p-p38-MAPK & {$[106]$} \\
\hline & High glucose-induced zebrafish & $20 \mu \mathrm{M} 16 \mathrm{~h}$ prior to glucose & $\downarrow \mathrm{NO}^{\bullet}, \mathrm{iNOS}$ and COX-2 & [35] \\
\hline & UVB-irradiated zebrafish embryos & $50 \mu \mathrm{M} 1 \mathrm{~h}$ prior to irradiation $\left(50 \mathrm{~mJ} / \mathrm{cm}^{2}\right)$ & $\downarrow \mathrm{NO}^{\circ}$ & [107] \\
\hline
\end{tabular}


Table 2. Cont.

\begin{tabular}{|c|c|c|c|c|}
\hline Extract/Compound & Model & Conditions & Effect & Ref. \\
\hline Eckol comercial & $\mathrm{CCl}_{4}$-injured livers of Kunming mice & $\begin{array}{l}0.5 \text { and } 1.0 \mathrm{mg} \text { compound } / \mathrm{kg} / \text { day orally } \\
\text { administered over } 7 \text { days before i.p. } 0.5 \% \mathrm{CCl}_{4}\end{array}$ & $\downarrow$ IL- $1 \beta$, IL- 6 and TNF- $\alpha, \uparrow$ IL-10 & [67] \\
\hline Eckol from Ecklonia cava & UVB-irradiated zebrafish embryos & $50 \mu \mathrm{M} 1 \mathrm{~h}$ prior to irradiation $\left(50 \mathrm{~mJ} / \mathrm{cm}^{2}\right)$ & $\downarrow \mathrm{NO}^{\bullet}$ & {$[107]$} \\
\hline \multirow{2}{*}{ Eckol from Eisenia arborea } & AA, TPA, OXA-induced ear edema in ICR mice & $\begin{array}{l}\text { Topical application }(0.01-0.1 \mathrm{mg} / \mathrm{mL}) \text { with } \\
\text { each sensitizer }\end{array}$ & $\begin{array}{l}\downarrow \text { swelling up to } 49 \%, 38 \% \text { and } \\
65 \% \text {, respectively }\end{array}$ & [105] \\
\hline & AA, TPA, OXA-induced ear edema & $\begin{array}{l}\text { Oral gavage of } 75 \mathrm{nmol}, 18 \mathrm{~h} \text { prior to } \\
\text { each sensitizer }\end{array}$ & $\begin{array}{l}\downarrow \text { swelling } 13 \%, 40 \% \text { and } \\
19 \% \text {, respectively }\end{array}$ & [104] \\
\hline Eckol from Eisenia bicyclis & Acetic acid-induced ICR mice & $20 \mu \mathrm{M}, 6 \mathrm{~h}$ prior to i.p. $0.7 \%$ acetic acid & $\begin{array}{l}\downarrow C A M s \text { and adhesion and } \\
\text { migration of leucocytes }\end{array}$ & [79] \\
\hline Eckstolonol from Ecklonia cava & UVB-irradiated zebrafish embryos & $50 \mu \mathrm{M} 1 \mathrm{~h}$ prior to irradiation $\left(50 \mathrm{~mJ} / \mathrm{cm}^{2}\right)$ & $\downarrow \mathrm{NO}^{\bullet}$ & [107] \\
\hline Phlorofucofuroeckol-A from Eisenia arborea & AA, TPA, OXA-induced ear edema in ICR mice & $\begin{array}{l}\text { Topical application }(0.01-0.1 \mathrm{mg} / \mathrm{mL}) \text { with } \\
\text { each sensitizer }\end{array}$ & $\begin{array}{l}\downarrow \text { swelling up to } 68 \%, 44 \% \text { and } \\
77 \% \text {, respectively }\end{array}$ & [105] \\
\hline Pholorofucofuroeckol-A from Eisenia bicyclis & AA, TPA, OXA-induced ear edema & $\begin{array}{l}\text { Oral gavage of } 75 \mathrm{nmol}, 18 \mathrm{~h} \text { prior to } \\
\text { each sensitizer }\end{array}$ & $\begin{array}{l}\downarrow \text { swelling } 31 \%, 32 \% \text { and } \\
23 \% \text {, respectively }\end{array}$ & [104] \\
\hline Phlorofucofuroeckol-B from Eisenia arborea & AA, TPA, OXA-induced ear edema & $\begin{array}{l}\text { Oral gavage of } 75 \mathrm{nmol}, 18 \mathrm{~h} \text { prior to } \\
\text { each sensitizer }\end{array}$ & $\begin{array}{l}\downarrow \text { swelling } 42 \%, 38 \% \text { and } \\
41 \% \text {, respectively }\end{array}$ & [104] \\
\hline Phloroglucinol commercial & Acetic acid-induced ICR mice & $20 \mu \mathrm{M}, 6 \mathrm{~h}$ prior to i.p. $0.7 \%$ acetic acid & $\begin{array}{l}\downarrow \mathrm{CAMs} \text { and adhesion and } \\
\text { migration of leucocytes }\end{array}$ & [79] \\
\hline Phloroglucinol from Ecklonia cava & UVB-irradiated zebrafish embryos & $50 \mu \mathrm{M} 1 \mathrm{~h}$ prior to irradiation $\left(50 \mathrm{~mJ} / \mathrm{cm}^{2}\right)$ & $\downarrow \mathrm{NO}^{\bullet}$ & [107] \\
\hline Triphlorethol A from Ecklonia cava & UVB-irradiated zebrafish embryos & $50 \mu \mathrm{M}, 1 \mathrm{~h}$ prior to irradiation $\left(50 \mathrm{~mJ} / \mathrm{cm}^{2}\right)$ & $\downarrow \mathrm{NO}^{\bullet}$ & [107] \\
\hline
\end{tabular}

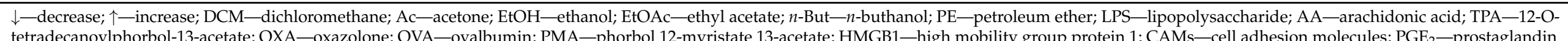

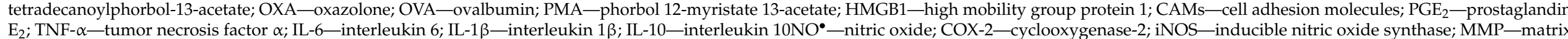

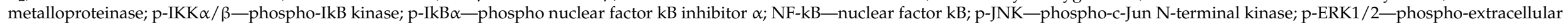

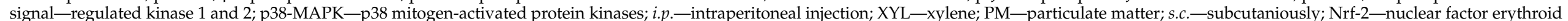

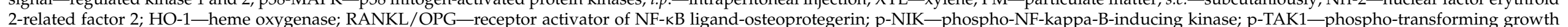
factor- $\beta$-activated kinase 1 ; UVB-ultraviolet- $\mathrm{B} ; \mathrm{CoCl}_{2}$ - cobalt chloride; $\mathrm{CCl}_{4}$ - carbon tetrachloride. 
In a different study, Lee et al. [108] reported that in addition to the Akt/IKB-mediated NF- $\mathrm{kB}$ inactivation, dieckol also caused the decrease of $\mathrm{p} 38$ and ERK phosphorylation in three different human hepatic cell lines, which is partially in agreement with a previous work carried out on LPS-stimulated BV2 cells in which this compound only inhibited p38-MAPK but not ERK nor JNK [81]. Similar observations were described for phlorofucofuroeckol A, which inhibited the phosphorylation of p38, ERK and JNK in LPS-stimulated Raw 264.7 cells [96], and for phloroglucinol, which blocked the phosphorylation of ERK in HT1080 cells [54], both resulting in the suppression of AP-1 activity, another transcription factor involved in the regulation of some pro-inflammatory mediators such as matrix metalloproteinases, a group of enzymes involved in the tissue remodeling during chronic inflammation and cell motility further in a tumor environment. The inhibitory effects of these and other isolated phlorotannins such as eckol, eckstolonol, 6,6'-bieckol, 8,8'-bieckol, fucofuroeckol-A over NF-KB and MAPKs have been reported in multiple cell lines elicited with different pro-inflammatory stimulus, including LPS-induced BV2 microglia cells, THP-1 or Raw 264.7 macrophages, $\mathrm{A} \beta_{25-35}$-stimulated PC12 pheochromocytoma cells, PMA-induced MG-63 human osteosarcoma cells, high glucose-induced HUVEC endothelial cells, hypoxia-induced primary mouse hepatocytes and gamma-irradiated primary rat hepatocytes $[46,65,81,82,88,89,106,109-112]$, suggesting that these compounds may act in a wide range of inflammatory conditions.

A common method to evaluate the anti-inflammatory properties of a potential therapeutic compound in vivo is through the induction of ear or paw edema in mice, usually with PMA or carrageenan. Indeed, using this method, Joung et al. [100] found that the topical administration of Myagropsis myagroides ethanolic extract in ICR mice ears ( $90 \mu \mathrm{g} / \mathrm{ear}$ ) as well as 6,6'-bieckol ( $30 \mu \mathrm{g} /$ ear) isolated from the same species prior to the induction of ear edema with PMA significantly suppressed the ear swelling in approximately $67 \%$ and $64 \%$, respectively, which was very close to the effects observed for indomethacin, used as positive control (at $1 \mathrm{mg} /$ ear) [100]. Similarly, attenuation of ear swelling was described for phlorotannin purified extracts of Cystoseira sedoides, Cladostephus spongiosis and Padina pavonica as well as pure compounds such as eckol, 6,6'-bieckol, 6,8'-bieckol, 8,8' bieckol, phlorofucofuroeckol A and phlorofucofuroeckol $\mathrm{B}$ in mice ear edemas induced with several different sensitizers including arachidonic acid (AA), 12-O-tetradecanoylphorbol13-acetate (TPA), oxazolone (OXA) and xylene (XYL) [98,103-105]. Paw edema induced by carrageenan injection was also attenuated on Wistar rats treated with intraperitoneal injection of a phlorotannin purified extract of $C$. sedoides [98]. In BALB/c mice, topical application of Sargassum fulvellum phlorotannin purified fraction prior to UV-B irradiation effectively suppressed the protein expression of TNF- $\alpha$, COX-2 and iNOS, and their downstream products, $\mathrm{PGE}_{2}$ and $\mathrm{NO}^{\bullet}$, respectively [94], while in UV-B-irradiated zebrafish embryos, the treatment with phloroglucinol, triphlorethol A or eckstolonol all prevented the rise of the levels of $\mathrm{NO}^{\bullet}$ [107]. Likewise, diminished $\mathrm{NO}^{\bullet}$ levels as well as iNOS and COX-2 expression were described on zebrafish exposed to high glucose levels and treated with dieckol [35]. Oral administration of dieckol to LPS-induced septic shock in C57BL/ 6 mice over seven days, was also found to significantly decrease the blood serum levels of $\mathrm{NO}^{\bullet}, \mathrm{PGE}_{2}$ and high-mobility group box-1 (HMGB-1), improving their survival rates in a dose-dependent manner [101], whereas the oral administration of eckol to Kunming mice for an equal period of time effectively suppressed the expression of TNF- $\alpha$, IL- $1 \beta$ and IL-6, and enhanced the levels of IL-10 on the $\mathrm{CCl}_{4}$-injured livers [67]. More recently, Sanjeewa et al. [99] reported that the expression of these pro-inflammatory cytokines as well as iNOS and COX-2 were inhibited at the mRNA level and the phosphorylation of MAPKs were suppressed in the lung tissues of particular matter and ovalbumin-exposed $\mathrm{BALB} / \mathrm{c}$ mice treated with $S$. horneri ethanol extract by oral ingestion over 15 days. Notably, in an intervention study carried out on human volunteers, the oral administration of a capsule containing $A$. nodosum polyphenol extract seems to attenuate the ex vivo production of IL-6 in blood samples cultured with LPS, although no statistical significance was achieved [102]. 


\subsection{Role in Cancer}

The fact that phlorotannins can counteract oxidative and inflammatory states make them able to indirectly display some potential to prevent and/or mitigate oxidative stressor inflammation-based tumor initiation and progression. Notwithstanding, the role of phlorotannins as anti-neoplastic agents has been suggested to go much further, with several authors reporting that these compounds may act as anti-proliferative, antimetastatic and anti-angiogenic agents at different types of cancer (Table 3). According to Nwosu et al. [12], both phlorotannin-purified extracts from A. nodosum and Alaria esculenta exhibited dosedependent anti-proliferative effects on Caco-2 growth showing $\mathrm{IC}_{50}$ values of $33 \mu \mathrm{g} / \mathrm{mL}$ and $7 \mu \mathrm{g} / \mathrm{mL}$, respectively. Similarly, the phenolic-rich extracts of three different Cystoseira species (C. sedoides, C. compressa and C. crinita) demonstrated promising growth inhibitory effects against three different tumor cell lines, namely A549 lung cell carcinoma cells, HCT15 colon cell carcinoma cells and MCF-7 breast adenocarcinoma cells, although their IC $_{50}$ values $(17.9-90.3 \mu \mathrm{g} / \mathrm{mL})$ were much higher when compared with those of cisplatin $(1.5-1.9 \mu \mathrm{g} / \mathrm{mL})$, an important chemotherapeutic drug used for the treatment of several neoplasms. However, when tested on normal cells, i.e., non-tumor cells (Mardin-Darby canine kidney cells and rat fibroblasts), it was found that all the three Cystoseira extracts presented much lower toxicity than cisplatin, suggesting that, although their antitumor capacity may be weaker compared to the commercial drug, their specificity for tumor cells is much higher, and thus administration of higher doses could be possible for achieving the desired antitumor effect without compromising the viability of normal cells [113]. In fact, according to the work of Ahn et al. [114] carried out in xenograft mice models implanted with SKOV3 ovarian cancer cells, the oral administration of dieckol (300 mg/ $\mathrm{kg} /$ week) was even more effective than cisplatin $(9 \mathrm{mg} / \mathrm{kg} /$ week $)$ at suppressing the tumor growth without showing any liver or kidney toxicity, while the cisplatin-treated mice revealed increased blood urea nitrogen and serum creatinine which are indicative of kidney dysfunction.

Table 3. Antitumor activity of phlorotannins extracts and isolated phlorotannins from brown macroalgae.

\begin{tabular}{|c|c|c|c|c|}
\hline Extract/Compound & Model & Conditions & Effect & Ref. \\
\hline \multicolumn{5}{|c|}{ Saccharina japonica } \\
\hline MAE with EtOH 55\% & HepG2 cells & $\begin{array}{c}\text { Incubation with } \\
0.2-2 \mathrm{mg} / \mathrm{mL} \text { for } 24 \mathrm{~h}\end{array}$ & $\downarrow$ cell prolif. & [115] \\
\hline \multicolumn{5}{|c|}{ Ascophyllum nodosum } \\
\hline $\begin{array}{l}\mathrm{ACN}: 0.2 \% \mathrm{CH}_{2} \mathrm{O}_{2}(1: 1) \rightarrow \\
\text { purification in SPE columns }\end{array}$ & Caco- 2 cells & $\begin{array}{c}\text { Incubation with } \\
0-50 \mu \mathrm{g} / \mathrm{mL} \text { for } 72 \mathrm{~h}\end{array}$ & $\downarrow$ cell prolif. (IC $50=33 \mu \mathrm{g} / \mathrm{mL})$ & [12] \\
\hline \multicolumn{5}{|c|}{ Alaria esculenta } \\
\hline $\begin{array}{l}\mathrm{ACN}: 0.2 \% \mathrm{CH}_{2} \mathrm{O}_{2}(1: 1) \rightarrow \\
\text { purification in SPE columns }\end{array}$ & Caco- 2 cells & $\begin{array}{c}\text { Incubation with } \\
0-50 \mu \mathrm{g} / \mathrm{mL} \text { fot } 72 \mathrm{~h}\end{array}$ & $\downarrow$ cell prolif. $\left(\mathrm{IC}_{50}=7 \mu \mathrm{g} / \mathrm{mL}\right)$ & [12] \\
\hline \multicolumn{5}{|c|}{ Cystoria sedoides } \\
\hline MAE with EtOH 50\% & MCF-7 cells & $\begin{array}{c}\text { Incubation with } \\
10-200 \mu \mathrm{g} / \mathrm{mL} \text { for } 24 \mathrm{~h}\end{array}$ & $\downarrow$ cell prolif. & [116] \\
\hline \multicolumn{5}{|c|}{ Cystoseira spp. } \\
\hline $\mathrm{H}_{2} \mathrm{O}$ extract & $\begin{array}{l}\text { Tumor cells: A549, } \\
\text { HCT15 and MCF-7 cells } \\
\text { Normal cells: MDCK } \\
\text { cells and rat fibroblasts }\end{array}$ & $\begin{array}{c}\text { Incubation with } \\
25-250 \mu \mathrm{g} / \mathrm{mL} \text { for } 48 \mathrm{~h}\end{array}$ & $\begin{array}{c}\text { Tumor cells: } \downarrow \text { cell prolif. } \\
\left.\text { (IC } \mathrm{IC}_{50}=17.9-90.3 \mu \mathrm{g} / \mathrm{mL}\right) \\
\text { Normal cells: } \downarrow \text { toxicity } \\
\text { than cisplatin }\end{array}$ & [113] \\
\hline \multicolumn{5}{|c|}{ Fucus evanescens } \\
\hline $\mathrm{EtOH} 60 \%$ & DLD-1 and HT-29 cells & $\begin{array}{l}\text { Incubation with } 50 \mu \mathrm{g} / \mathrm{mL} \\
\text { for } 30 \mathrm{~d}\end{array}$ & $\begin{array}{c}\downarrow \text { cell prolif. by } 67 \% \text { and } \\
63 \% \text {, respectively }\end{array}$ & [117] \\
\hline
\end{tabular}


Table 3. Cont.

\begin{tabular}{|c|c|c|c|c|}
\hline Extract/Compound & Model & Conditions & Effect & Ref. \\
\hline \multicolumn{5}{|c|}{ Laminaria cichorioides } \\
\hline EtOH $60 \%$ & DLD-1 and HT-29 cells & $\begin{array}{l}\text { Incubation with } 50 \mu \mathrm{g} / \mathrm{mL} \\
\text { for } 30 \mathrm{~d}\end{array}$ & $\begin{array}{c}\downarrow \text { cell prolif. by } 64 \% \text { and } 56 \% \text {, } \\
\text { respectively (July specimen) } \\
\downarrow \text { cell prolif. by } 50 \% \text { and } \\
52 \% \text {, respectively } \\
\text { (September specimen) }\end{array}$ & [117] \\
\hline \multicolumn{5}{|c|}{ Costaria costata } \\
\hline EtOH $60 \%$ & DLD-1 and HT-29 cells & $\begin{array}{l}\text { Incubation with } 50 \mu \mathrm{g} / \mathrm{mL} \\
\text { for } 30 \mathrm{~d}\end{array}$ & $\begin{array}{l}\downarrow \text { cell prolif. by } 38 \% \text { and } 31 \% \text {, } \\
\text { respectively (May's specimen) } \\
\downarrow \text { cell prolif. by } 50 \% \text { and } 44 \% \text {, } \\
\text { respectively (July specimen) }\end{array}$ & [117] \\
\hline \multicolumn{5}{|c|}{ Macrocystis integrifolia } \\
\hline $\begin{array}{l}\mathrm{MeOH} \rightarrow \text { Fract. with } n \text {-hex, } \\
\mathrm{H}_{2} \mathrm{O}: \text { EtOAc (2:3) and 1-But } \rightarrow \\
\text { subfraction of } 1 \text {-But }\end{array}$ & HeLa cells & $\begin{array}{c}\text { Incubation with } \\
0.5-5 \mathrm{mg} / \mathrm{mL} \text { for } 72 \mathrm{~h}\end{array}$ & $\begin{array}{c}\downarrow \text { cell prolif. } \\
\left(\mathrm{EC}_{50}=4.11 \mathrm{mg} / \mathrm{mL}\right)\end{array}$ & [118] \\
\hline \multicolumn{5}{|c|}{ Nereocystis leutkeana } \\
\hline $\begin{array}{c}\mathrm{MeOH} \rightarrow \text { Fract. with } n \text {-hex } \rightarrow \\
\mathrm{H}_{2} \mathrm{O}+\text { EtOAc }(2: 3) \rightarrow 1 \text {-But }\end{array}$ & HeLa cells & $\begin{array}{c}\text { Incubation with } \\
0.5-5 \mathrm{mg} / \mathrm{mL} \text { for } 72 \mathrm{~h}\end{array}$ & $\begin{array}{c}\downarrow \text { cell prolif. } \\
\left(\mathrm{EC}_{50}=4.10 \mathrm{mg} / \mathrm{mL}\right)\end{array}$ & [118] \\
\hline \multicolumn{5}{|c|}{ Laminaria setchellii } \\
\hline $\begin{array}{c}\mathrm{MeOH} \rightarrow \text { Fract. with } n \text {-hex } \rightarrow \\
\mathrm{H}_{2} \mathrm{O}+\text { EtOAc }(2: 3) \rightarrow 1 \text {-But }\end{array}$ & HeLa cells & $\begin{array}{c}\text { Incubation with } \\
0.5-5 \mathrm{mg} / \mathrm{mL} \text { for } 72 \mathrm{~h}\end{array}$ & $\begin{array}{c}\downarrow \text { cell prolif. } \\
\left(\mathrm{EC}_{50}=4.53 \mathrm{mg} / \mathrm{mL}\right)\end{array}$ & [118] \\
\hline \multicolumn{5}{|c|}{ Sargassum muticum } \\
\hline $\begin{array}{c}\text { PLE with EtOH 95\% } \rightarrow \text { Fract. } \\
\text { with } \mathrm{DCM} \rightarrow \mathrm{Ac} \rightarrow \\
\text { EtOH } \rightarrow \text { EtOAC }\end{array}$ & HT-29 cells & $\begin{array}{l}\text { Incubation with } \\
12.5-100 \mu \mathrm{g} / \mathrm{mL} \text { for } \\
24,48 \text { and } 72 \mathrm{~h}\end{array}$ & $\begin{array}{c}\downarrow \text { cell prolif. by } 50 \% \text { after } 24 \mathrm{~h} \\
\text { with } 50 \mu \mathrm{g} / \mathrm{mL} \text { of extract } \\
\text { (Norway specimen) }\end{array}$ & [119] \\
\hline \multicolumn{5}{|c|}{ Fucus vesiculosus } \\
\hline $\begin{array}{c}\text { Ac } 99.5 \% \rightarrow \text { purification } \\
\text { by HPLC }\end{array}$ & $\begin{array}{l}\text { PancTu1, Panc89, Panc1 } \\
\text { and Colo357 cells }\end{array}$ & $\begin{array}{c}\text { Incubation with } \\
0.01-100 \mu \mathrm{g} / \mathrm{mL} \text { for } 24 \mathrm{~h}\end{array}$ & $\begin{array}{c}\downarrow \text { cell prolif., } \uparrow \text { cell cycle } \\
\text { inhibitors }\left(\mathrm{EC}_{50}=17.35,17.5,\right. \\
19.23 \text { and } 28.9 \mu \mathrm{g} / \mathrm{mL} \text {, for each } \\
\text { cell line, respectively) }\end{array}$ & [120] \\
\hline \multicolumn{5}{|c|}{ Ecklonia cava } \\
\hline $\begin{array}{c}\text { MeOH } 70 \% \rightarrow \text { Fract. } n \text {-hex } \rightarrow \\
\text { DCM } \rightarrow \text { EtOAc }\end{array}$ & A549 cells & $\begin{array}{c}\text { Incubation with } \\
0-200 \mu \mathrm{g} / \mathrm{mL} \text { for } 24 \text { or } 48 \mathrm{~h}\end{array}$ & $\downarrow$ exp. of MMP-2 & [121] \\
\hline EtOH 95\% & HDFs and HT1080 cells & $\begin{array}{c}\text { Incubation with } \\
10-1000 \mu \mathrm{g} / \mathrm{mL} \text { for } 3 \mathrm{~d}\end{array}$ & $\downarrow$ exp. of MMP-2 and -9 & [122] \\
\hline EtOH extract & A2780 and SKOV3 cells & $\begin{array}{l}\text { Incubation with serial } \\
\text { dilutions for } 24 \mathrm{~h}\end{array}$ & $\begin{array}{c}\downarrow \text { cell prolif. }\left(\mathrm{IC}_{50}=84.3 \text { and }\right. \\
99.6 \mu \mathrm{g} / \mathrm{mL}, \text { respectively) }\end{array}$ & [114] \\
\hline \multicolumn{5}{|c|}{ Ishige okamurae } \\
\hline $\begin{array}{l}\mathrm{EtOH} \rightarrow \text { Fract. } \mathrm{H}_{2} \mathrm{O} \rightarrow n \text {-But } \\
\quad \rightarrow \mathrm{MeOH} 85 \% \rightarrow n \text {-hex }\end{array}$ & HT1080 cells & $\begin{array}{l}\text { Incubation with } 5 \text { or } \\
50 \mu \mathrm{g} / \mathrm{mL} \text { for } 24 \mathrm{~h}\end{array}$ & $\begin{array}{l}\downarrow \text { exp. of MMP-2 and }-9 ; \\
\uparrow \text { exp. TIMP-1 and }-2\end{array}$ & [123] \\
\hline \multicolumn{5}{|c|}{ Isolated compounds } \\
\hline 6,6'-Bieckol from Ecklonia cava & HT1080 cells & $\begin{array}{c}\text { Incubation with } \\
5-100 \mu \mathrm{g} / \mathrm{mL} \text { for } 48 \mathrm{~h}\end{array}$ & $\begin{array}{l}\downarrow \text { exp. of MMP-2 and }-9 \text { and } \\
\text { exp. of NF- } k B \text { p50 and p } 65\end{array}$ & [124] \\
\hline
\end{tabular}


Table 3. Cont.

\begin{tabular}{|c|c|c|c|c|}
\hline Extract/Compound & Model & Conditions & Effect & Ref. \\
\hline \multirow[t]{2}{*}{ Dieckol commercial } & $\begin{array}{l}\text { In vitro: SKOV3 cells } \\
\text { In vivo: } \\
\text { SKOV3-xenograft in } \\
\text { BALB/c mice }\end{array}$ & $\begin{array}{l}\text { In vitro: Incubation with } \\
80-120 \mu \mathrm{M} \text { for } 24 \mathrm{~h} \\
\text { In vivo: oral } \\
\text { administration of } 50 \text { and } \\
100 \mathrm{mg} / \mathrm{mL} 3 \mathrm{~d} \text { a week } \\
\text { for } 28 \text { days }\end{array}$ & $\begin{array}{c}\text { In vitro: } \uparrow \text { exp. of casp-3, }-8 \\
\text { and }-9 ; \downarrow \text { exp. of the XIAP, } \\
\text { FLIP and Bcl-2 } \\
\text { In vivo: } \downarrow \text { cell prolif. and lower } \\
\text { toxicity than cisplatin }\end{array}$ & [114] \\
\hline & A549 cells & $\begin{array}{l}\text { Incubation with } \\
25-50 \mu \mathrm{g} / \mathrm{mL} \text { for } 24 \mathrm{~h}\end{array}$ & $\begin{array}{c}\uparrow \text { exp. of casp-3, }-8 \text { and }-9, \\
\text { of tumor suppressor } \\
\text { protein E-cadherin }\end{array}$ & [125] \\
\hline \multirow{4}{*}{ Dieckol from Ecklonia cava } & $\begin{array}{l}\text { NDEA-induced } \\
\text { Wistar rats }\end{array}$ & $\begin{array}{l}\text { Oral administration of } \\
40 \mathrm{mg} / \mathrm{kg} / \mathrm{d} \text { for } 15 \text { weeks }\end{array}$ & $\begin{array}{c}\downarrow \text { exp. of Bcl-2, VEGF, MMP-2 } \\
\text { and }-9, \uparrow \text { exp. of Bax, } \\
\text { cytochrome c and casp-3 }\end{array}$ & [126] \\
\hline & MCF-7 cells & $\begin{array}{l}\text { Incubation with } 1-100 \mu \mathrm{M} \\
\text { for } 48 \mathrm{~h}\end{array}$ & $\begin{array}{c}\downarrow \text { cell migration, exp. of } \\
\text { MMP-9 and VEGF, } \uparrow \text { exp. of } \\
\text { TIMP- } 1 \text { and }-2\end{array}$ & [127] \\
\hline & $\begin{array}{l}\text { TPA-induced } \\
\text { SK-Hep1 cells }\end{array}$ & $\begin{array}{l}\text { Incubation with } 1-50 \mu \mathrm{M} \\
\text { for } 1.5 \mathrm{~h}\end{array}$ & $\begin{array}{c}\downarrow \text { exp. of MMP-9 and exp. of } \\
\text { p-ERK } 1 / 2, \text { p-MEK } 1 / 2 \text { and } \\
\text { p-JNK } 1 / 2\end{array}$ & [128] \\
\hline & $\begin{array}{l}\text { LPS-induced } \\
\text { MDA-MB-231 cells }\end{array}$ & $\begin{array}{l}\text { Incubation with } 50 \mu \mathrm{M} \\
\text { for } 48 \mathrm{~h}\end{array}$ & $\begin{array}{l}\downarrow \text { cell invasion, exp. of TLR-4, } \\
\text { NF- } \kappa \text { B and MMP-2 and }-9\end{array}$ & [129] \\
\hline $\begin{array}{c}\text { Dieckol from } \\
\text { Ecklonia stolonifera }\end{array}$ & Hep3B cells & $\begin{array}{l}\text { Incubation with } 70-110 \mu \mathrm{M} \\
\text { for } 24 \mathrm{~h}\end{array}$ & $\begin{array}{c}\uparrow \text { exp. of casp }-3,-7,-8 \text { and }-9, \\
\text { Bid and Bim }\end{array}$ & [130] \\
\hline Eckol commercial & $\begin{array}{l}\text { S180-xenograft in } \\
\text { Kumming mice }\end{array}$ & $\begin{array}{l}\text { Oral administration of } \\
0.25-1 \mathrm{mg} / \mathrm{kg} / \mathrm{d} \text { for } 7 \mathrm{~d} \\
\text { before and } 10 \mathrm{~d} \\
\text { after xenograft }\end{array}$ & $\begin{array}{l}\uparrow \text { exp. of casp-3 and -9, } \\
\downarrow \text { exp. of Bcl-2, Bax, EGFR } \\
\text { and p-EGFR }\end{array}$ & [131] \\
\hline Eckstolonol from Ecklonia cava & MCF-7 cells & $\begin{array}{l}\text { Incubation with } 5-110 \mu \mathrm{M} \\
\text { for } 48 \mathrm{~h}\end{array}$ & $\begin{array}{c}\downarrow \text { exp. of Bcl-2, } \uparrow \text { exp. of casp-3 } \\
\text { and }-9, \text { Bax and tumor } \\
\text { suppressor p53 }\end{array}$ & [132] \\
\hline \multirow[t]{2}{*}{ Phloroglucinol commercial } & HT-29 cells & $\begin{array}{l}\text { Incubation with } \\
12.5-50 \mu \mathrm{g} / \mathrm{mL} \text { for } 24 \mathrm{~h}\end{array}$ & $\begin{array}{c}\uparrow \text { exp. of casp-3 and -8, } \\
\text { cytochrome c, Apaf-1, Bad and } \\
\text { Bax, } \downarrow \text { exp. of Bcl-2, Bcl-XL }\end{array}$ & [133] \\
\hline & HT-29 cells & $\begin{array}{c}\text { Incubation with } \\
0-50 \mu \mathrm{g} / \mathrm{mL} \text { for } 24 \mathrm{~h}\end{array}$ & $\downarrow$ exp. of IGFR-1 & [134] \\
\hline $\begin{array}{l}\text { Phlorofucofuroeckol A from } \\
\text { Eisinia bicyclis }\end{array}$ & $\begin{array}{l}\text { HCT116, SW480, LoVo } \\
\text { and HT-29 cells }\end{array}$ & $\begin{array}{l}\text { Incubation with } 100 \mu \mathrm{M} \\
\text { for } 24 \mathrm{~h}\end{array}$ & $\uparrow$ exp. of ATF3 & [135] \\
\hline $\begin{array}{l}\text { Phlorofucofuroeckol A from } \\
\text { Ecklonia cava }\end{array}$ & $\begin{array}{l}\text { LPS-induced } \\
\text { MDA-MB-231 cells }\end{array}$ & $\begin{array}{l}\text { Incubation with } 50 \mu \mathrm{M} \\
\text { for } 48 \mathrm{~h}\end{array}$ & $\begin{array}{l}\downarrow \text { cell invasion, exp. of TLR- } 4 \text {, } \\
\text { NF- } k B \text { and MMP- } 2 \text { and }-9\end{array}$ & [129] \\
\hline
\end{tabular}

$\downarrow$-decrease; $\uparrow$-increase; ACN-acetonitrile; Apaf-1—apoptotic protease activating factor 1; ATF3—cyclic AMP-dependent transcription factor; Bad-Bcl-2 associated agonist of cell death; Bax-Bcl-2-associated X protein; Bcl-2-B-cell lymphoma 2; Bcl-XL-B-cell lymphomaextra-large; Bid-BH3 interacting domain death agonist; Bim—Bcl-2-like protein 11; DCM-dichloromethane; ERK 1/2 - extracellular signal—regulated kinase 1 and 2; EGFR—epiderma growth factor; $\mathrm{CH}_{2} \mathrm{O}_{2}$ - formic acid; $\mathrm{MeOH}$-methanol; Ac—acetone; EtOH—ethanol; EtOAc—ethyl acetate; $n$-hex— $n$-hexane; $n / 1$-But—n/1-buthanol; FLIP-FLICE-inhibitory protein; HPLC—high performance liquid chromatography; IGFR-1—insulin-like growth factor 1 receptor; MAE-microwave-assisted extraction; p-MEK 1/2-phosphor-MAP kinase kinase 1 and 2; SPE—-solid phase extraction; PLE—pressurized liquid extraction; NF- $\mathrm{kB}$ - nuclear factor $\mathrm{kB}$; NDEA-N-nitrosodiethylamine; p-JNK 1/2 - phospho-c-Jun N-terminal kinase 1 and 2; TLR-4-Toll-like receptor 4; TPA-12-O-Tetradecanoylphorbol-13-acetate; LPSlipopolysaccharides; MMP — matrix metalloproteinase; exp.—expression; prolif.—proliferation; casp—caspase; TIMP—tissue inhibitor of metalloproteinases; VEGF - vascular endothelial growth factor; XIAP-X-linked inhibitor of apoptosis protein. Cell lines: caco-2human colon cancer; MDCK-Mardin-Darby canine kidney; HeLa-human cervical adenocarcinoma; PancTu1-human pancreatic cancer; Colo357-human pancreatic adenosquamous carcinoma; Panc89-human pancreatic cancer; and Panc1—pancreatic carcinoma; A549-human lung adenocarcinoma; MCF-7-human breast adenocarcinoma; HCT15-human colorectal adenocarcinoma; DLD-1-human colorectal adenocarcinoma; HT-29-human colorectal adenocarcinoma; Hep3B-human hepatocellular carcinoma; HDFs-human dermal fibroblasts; SK-Hep1—human hepatocellular carcinoma; HT1080—human fibrosarcoma; HCT116-human colon cancer; SW480-human colon cancer; LoVo-human colorectal cancer; A2780 - human ovarian carcinoma; SKOV3 — human ovarian carcinoma; MDA-MB-231human breast cancer; S180-murine sarcoma cancer; HepG2-human liver hepatocellular carcinoma. 
Many authors have reported a causality link between the phlorotannin content of the extracts and the extracts' anti-proliferative effects. This is the case of the work reported by Imbs et al. [117], who found that among three different seaweeds, namely Fucus evanescens, Laminaria cichorioides and Costaria costata, the $60 \%$ ethanolic extract from the former, which was the highest in polyphenols (10.1\% dry matter), displayed the strongest inhibitory effects on DLD-1 and HT-29 human colorectal adenocarcinoma cells growth $67 \%$ and $63 \%$, respectively), while the extract from L. cichorioides harvested in May, which had the lowest polyphenol content (1.4\% dry matter), exhibited the lowest inhibitory capacity ( $9 \%$ and $23 \%$ respectively). The authors reported identical observations for $C$. costata, since extracts from samples collected in May (phenolic content of $2.0 \%$ dry matter) exhibited slightly lower inhibitory effects than the extract from samples collected in July (phenolic content of $2.7 \%$ dry matter). These results are in agreement with a previous study carried out on HeLa cervical adenocarcinoma cells in which Macrocystis integrifolia and Nereocystis leutkeana methanolic extracts, both containing a phenolic content of $3.9 \mu \mathrm{g}$ gallic acid equivalents $/ \mathrm{g}$ extract, showed stronger anti-proliferative effect than the extract of Laminaria setchellii, which contained only $1.8 \mu \mathrm{g}$ gallic acid equivalents/g extract [118]. More recently, it has been demonstrated that ethanol extracts from S. muticum, collected along the North Atlantic coast during the same harvesting season, exhibited different anti-proliferative activities towards HT-29 cells according to their total phlorotannin content, i.e., the extracts from samples collected in Norway which had the highest phlorotannin contents (approximately $5 \mathrm{mg} / \mathrm{g}$ extract) displayed growth inhibitions almost two times stronger than those observed for samples from Portugal, which contained approximately $4 \mathrm{mg} / \mathrm{g}$ extract [119].

One of the most common mechanisms responsible for phlorotannins anti-proliferative activity is their capacity to interact with multiple mediators of the apoptotic signaling cascade and thus trigger cell death by inducing apoptosis $[115,116,130,131,133]$. In this context, a hydrophilic fraction obtained from $F$. vesiculosus acetone extract was shown to induce apoptosis in different pancreatic cell lines through cell cycle arrest, which is comparable to the effects of common chemotherapeutic drugs clinically used, such as gemcitabine [120]. Compounds such as phloroglucinol or dieckol have been reported for their capacity to stimulate the release of cytochrome $c$ from the mitochondria or the expression of several caspases including caspase-3, -7, -8 and -9 in different tumor cell lines [114,125,130-133]. Additionally, dieckol was found to dose-dependently upregulate the expression of Bid and Bim pro-apoptotic proteins in Hep3B hepatocarcinoma cells [130] and to downregulate the expression of the XIAP, FLIP and Bcl-2 anti-apoptotic proteins in SKOV3 ovarian cancer cells [114], while in MCF-7 breast cancer cells, the treatment with eckstolonol caused a dosedependent downregulation of the anti-apoptotic protein Bcl-2 along with the upregulation of the pro-apoptotic protein Bax and tumor suppressor p53 [132]. Likewise, simultaneous increase of the pro-apoptotic proteins Bak and Bax, and decrease of the anti-apoptotic proteins Bcl-2 and Bcl- $x_{\mathrm{L}}$ was described in HT-29 cells treated with increasing concentrations of phloroglucinol (12.5-50 $\mu \mathrm{g} / \mathrm{mL})$ [133]. Yet, Kang et al. [134] reported that this compound may also exert pro-apoptotic effects on this cell line via an alternative mechanism involving the suppression of insulin-like growth factor-1 receptor (IGF-1R) expression and consequently blocking the PI3K/Akt/mTOR and Ras/ERK-MAPK signaling pathways, both playing key roles in the cell survival, growth and metabolism in colon cancer. On the other hand, phlorofucofuroeckol A seems to have the capacity to stimulate the expression of activating transcription factor 3 (ATF3), consequently inducing apoptosis in four different colorectal tumor cell lines namely HCT116, SW480, LoVo and HT-29 cells [135].

In vivo antitumor effects of eckol in a sarcoma xenograft-bearing mice model, were demonstrated to be not only resultant from its capacity to interfere with the expression of caspase-3, caspase-9, Bcl-2 and Bax, but also from its capacity to inhibit the expression of epidermal growth factor receptor (EGFR), a transmembrane protein that is usually overexpressed in many cancer types, and to stimulate the mononuclear phagocytic system, recruiting and activating dendritic cells, promoting the tumor-specific Th1 responses, increasing the CD4+/CD8+ T lymphocyte ratio, and enhancing cytotoxic T lymphocyte 
responses. Therefore, in addition to its anti-proliferative properties, eckol also exerts antitumor effects via stimulation of the host immune response [131]. Using a different in vivo model, Sadeeshkumar et al. [126] observed that more than activating the pro-apoptotic mechanisms (modulating the Bcl-2 family proteins, cytochrome $c$ release and caspases expression), the administration of dieckol ( $40 \mathrm{mg} / \mathrm{kg}$ bw over 15 weeks) to Wistar rats with $\mathrm{N}$-nitrosodiethylamine-induced hepatocarcinogenesis significantly inhibited the expression of vascular endothelial growth factor (VEGF), involved in the tumor angiogenesis, and metalloproteinases-2 and -9 , both participating in the extracellular matrix processing and intimately related with tumor invasion and migration [126].

Indeed, antimetastatic effect is another characteristic of phlorotannins that greatly contributes for their antitumor properties. One of the mechanisms by which phlorotannins exert antimetastatic effects is through inhibition of the expression of matrix metalloproteinases (MMPs), which are important enzymes involved in degradation of extracellular matrix proteins and tissue remodeling and are associated with various physiological or pathological processes such as morphogenesis, angiogenesis and metastasis. Among these, MMP-2 and MMP-9 are of particular relevance since they are usually overexpressed in tumor cells and are capable of degrading type IV collagen of basement membrane, the first barrier for cancer invasion [136]. Inhibition of the expression of these two enzymes were described for E. cava phlorotannin-rich extracts on human fibroblasts, HT1080 fibrosarcoma cells [122] and A549 human lung cancer cells [121], while different solvent-partitioned fractions of Ishige okamurae were shown to not only inhibit MMP-2 and MMP-9 expressions, but also to enhance the levels of tissue inhibitor of MMPs (TIMP)-1 and TIMP-2 in HT1080 cells, at both gene and protein levels [123]. In TPA-induced human hepatoma cells, dieckol suppression of MMP-9 occurred via inhibition of the activity of ERK 1/2 and JNK kinases [128], while in HT1080 cells treated with 6,6'-bieckol both MMP-2 and MMP-9 were suppressed via inhibition of the NF- $\mathrm{KB}$ signaling pathway [124], evidencing the potential role of phlorotannins in inflammation-based tumor development and invasion. Identical findings were reported recently in LPS-stimulated MDA-MB-231 breast cancer cells, in which the treatment either with dieckol or phlorofucofuroeckol A (at 50 and $20 \mu \mathrm{M}$, respectively) significantly inhibited the cell migration and invasion via suppression of TLR-4/NF-KB-mediated expression of MMP-9 [129]. In a different breast cancer cell line (MCF-7 cells), Kim et al. [127] demonstrated that in addition to the inhibition of MMP-9 gene expression, dieckol was also capable stimulate the expression of TIMP-1 and TIMP-2, and even block the expression of VEGF, indicating that this compound may also contribute for the inhibition of tumor vascularization.

An alternative antimetastatic mechanism of dieckol was demonstrated in A549 lung cancer cells, in which migratory and invasive phenotype were remarkable abrogated via activation of tumor suppressor protein E-cadherin, an adhesion molecule that plays a key role in the epithelial-mesenchymal transition process, i.e., the mechanism by which epithelial cells lose their cell-cell adhesion characteristics and gain migratory/invasive properties [125].

\section{Patent Review}

The recovery of phlorotannins from brown macroalgae is a subject that is triggering a great economic interest, thus a domain open to technological innovations. These innovations are often translated in patents, i.e., legal documents that ensure the right of innovative inventions, in which the new product or process developed to answer a particular problem is described, with very meticulous technical information. Patent review is therefore a useful approach to have an idea of the progress made in a certain technological field. In Table 4 are described some examples of patents or patent applications filed for antioxidant, anti-inflammatory and anti-tumor products based on phlorotannins.

In 2006, Cosmax Co. (South Korea) filed the patent Ecklonia cava extract with high antioxidant activity describing a process for producing an extract from E. cava containing 10 to $15 \%$ of phlorotannins using supercritical extraction with $\mathrm{CO}_{2}$. The extracts produced this manner are claimed to exert high antioxidant activity and are intended for application 
as raw ingredients in the formulation of cosmetics and functional foods [137]. Later, in 2013, the University of Santiago de Compostela (Spain) filed the patent "Antioxidant extract from brown macroalgae and method for obtaining same" describing another method for production of phlorotannin-rich extracts. In this case, the invention relates to a method using ultrasound-assisted continuous aqueous extraction that is claimed to produce antioxidant extracts from $A$. nodosum containing $44.4 \mathrm{mg}$ of phloroglucinol equivalents/g extract and $B$. bifurcata containing $62.4 \mathrm{mg}$ of phloroglucinol equivalents/g extract. This invention was developed aiming the application of these extracts as active ingredients in cosmetic and food formulations [138].

Two applications for phlorotannin-based antioxidant compositions were filed by the Pukyong National University (South Korea). The first was filed in 2003 for a "Composition comprising phlorotannins isolated from the extract of Ecklonia stolonifera Okamura having anti-oxidative activity". This composition contains eckstolonol, eckstolonol pentaacetate, eckol, phlorofucofuroeckol A and dieckol isolated from E. cava and is aimed to be used either as a food preservative, to prevent oxidative spoilage, or as a pharmaceutical ingredient for the preparation of powders, granules, tablets, capsules, suspensions, emulsions, syrups and/or other formulations with anti-aging properties via inhibition of cell membrane lipid peroxidation [139]. In 2008 they filed a second patent for "An antioxidant active composition containing compounds from Ishige okamurae", describing a procedure to retrieve pure phlorotannin compounds from I. okamurae, namely phloroglucinol, 6,6'- bieckol and diphlorethohydroxycarmalol, through a conventional extraction method using methanol followed by solvent partitioning with different solvents and chromatography separation on Sephadex LH-20. The inventors showed that the compounds obtained with this method were highly effective at scavenging free radicals and reducing oxidative stress in different cells. As such, the inventors further describe an antioxidant composition using these compounds which is intended to be used as an active ingredient for the development of novel foods, cosmetics or pharmaceuticals targeting ROS-related diseases [140]. A third patent filed by this entity was registered in 2012, this time for an anti-inflammatory composition containing phlorotannin. This invention entitled "Anti-inflammatory composition containing phlorotannins from ecklonia stolonifera and Ecklonia cava extract as an effective component" consists of an anti-inflammatory composition composed of phlorofucofuroeckol-A isolated from E. cava and E. stolonifera via conventional extraction with ethanol and further purification using solvent partitioning and silica gel column chromatography. The inventors claim this composition has suppressive effects against both iNOS and COX2 expression, addressing it as an active ingredient to be applied in the formulation of pharmaceutical products including injectables, tablets, capsules or syrups for treating inflammatory diseases. An additional application as a functional ingredient for developing health promoting beverages is also included in this document [141].

In 2007 a patent entitled "Algae extract containing polyphenols", was filed by Diana Naturals (France), describing a method for producing an anti-inflammatory extract from Ascophyllum sp. and Fucus sp. via conventional extraction with water, following additional purifications and diafiltrations for removing alginates, iodine and low-molecular weight compounds. This extract, claimed to contain between 11 to $15 \%$ of polyphenols, was employed in an anti-inflammatory composition to be used with medicinal purposes for the prevention/treatment of inflammatory events, mainly targeting arthritis and allergy [142].

An innovative composition with anti-matrix metalloproteinase effects was registered in 2006 by Pukyong National University Industry-University Cooperation Foundation (South Korea) under the title "Composition containing phlorotannin for inhibition of matrix metalloproteinase activities". This innovative product contains phlorotannins from the eckol type, particularly dieckol and bieckol, which are claimed to inhibit the activity of the matrix metalloproteinase-1, $-2,-8$ and -9 more effectively than the tetracycline type pharmacological agents. Matrix metalloproteinases are collagenolytic enzymes involved in numerous diseases, including inflammation, hyperparathyroidism, diabetes, corneal ulcer, osteoporosis, gastric ulcer, cancer and metastasis. Therefore, this composition is aimed to be 
applied as an active ingredient in the formulation of powders, tablets, capsules, ointment compositions, solutions, gels, pastes, patches or granules for the multiple therapeutic approaches such as treating wound, cancer metastasis, rheumatoid arthritis, inflammation, hyperparathyroidism, diabetes, corneal ulcer, osteoporosis, stomach ulcer, acne, burn, periodontal diseases, arteriosclerosis and fracture [143]. The same entity also applied for two other inventions in 2010 and 2012. The first application describes "A composition containing eckol for inhibiting a growth of cancer stem cells", which suppresses Ras, a key intermediate in the regulation of cell proliferation and differentiation, through a Ras-RafERK signal transduction system. This composition is intended to be administered alone or in combination with another anticancer drug, namely temozolomide, for preventing growth of stem cancer cells, preferentially those that have the ability to differentiate into gliobastoma or brain cancer cells [144]. The second patent is related to the previous one and describes "An anti-cancer composition containing eckol for cancer expressing k-Ras". In this case, this composition is claimed to prevent tumorigeneses, growth and invasion of k-Ras-expressing cancers by suppressing both PI3K-Akt signaling and Ras signaling via Ras-Raf-ERK signal transduction system, without affecting other non-Ras expressing cells [145].

Overall, the research and innovation in this field of phlorotannins applied as antioxidants, anti-inflammatory or anti-tumor are slowly but steadily moving forward in a positive direction, with the Asian countries, particularly Korea, clearly leading the way since most of the patents filled are registered in this country.

Table 4. Patents/ patent applications for antioxidant, anti-inflammatory and antitumor products containing phlorotannin extracts (PhExt) or compounds.

\begin{tabular}{|c|c|c|c|c|}
\hline Product & Seaweed Species & Claims & Active Ingredients & $\begin{array}{l}\text { Patent/Patent } \\
\text { Application nr }\end{array}$ \\
\hline $\begin{array}{l}\text { PhExt with } \\
\text { antioxidant activity }\end{array}$ & E. cava & $\begin{array}{l}\text { Method for production of a } \\
\text { phlorotannin extract with high } \\
\text { antioxidant activity for } \\
\text { cosmetic application using } \\
\text { supercritical extraction }\end{array}$ & $\begin{array}{l}\text { E. cava extract with } \\
10 \%-15 \% \text { phlorotannins }\end{array}$ & KR20080004758A [137] \\
\hline $\begin{array}{l}\text { PhExt with } \\
\text { antioxidant activity }\end{array}$ & Bifurcaria bifurcata $+A$. nodosum & $\begin{array}{l}\text { Method for production of a } \\
\text { phlorotannin extract with } \\
\text { antioxidant activity for } \\
\text { cosmetic and food application } \\
\text { using ultrasound } \\
\text { assisted extraction }\end{array}$ & $\begin{array}{l}\text { B. bifurcate extract } \\
\text { containing } 62.4 \mathrm{mg} \text { eq. of } \\
\text { phloroglucinol } / \mathrm{g} \text { and } \\
\text { A. nodosum extract } \\
\text { containing } 44 \mathrm{mg} \text { eq. of } \\
\text { phloroglucinol } / \mathrm{g} \text {. }\end{array}$ & US2016074317A1 [138] \\
\hline $\begin{array}{l}\text { Antioxidant } \\
\text { composition }\end{array}$ & E. stolonifera & $\begin{array}{l}\text { Production of a composition of } \\
\text { several phlorotannins isolated } \\
\text { from E. stolonifera with high } \\
\text { antioxidant activity for } \\
\text { application in functional foods } \\
\text { to prevent oxidative spoilage or } \\
\text { pharmaceuticals for } \\
\text { preventing aging }\end{array}$ & $\begin{array}{l}\text { Eckstolonol, eckstolonol } \\
\text { pentaacetate, eckol, } \\
\text { phlorofucofuroeckol A } \\
\text { and dieckol }\end{array}$ & KR20040095125A [139] \\
\hline $\begin{array}{l}\text { Antioxidant } \\
\text { composition }\end{array}$ & I. okamurae & $\begin{array}{l}\text { Production of an antioxidant } \\
\text { composition containing } \\
\text { phlorotannins isolated from } \\
\text { I. okamurae for application in } \\
\text { pharmaceuticals, food } \\
\text { supplements and cosmetics } \\
\text { aiming the prevention of } \\
\text { ROS-related diseases }\end{array}$ & $\begin{array}{l}\text { Phloroglucinol, } \\
6,6 \text { '-bieckol or diphloretho- } \\
\text { hydroxycarmalol }\end{array}$ & KR20100039104A [140] \\
\hline
\end{tabular}


Table 4. Cont.

\begin{tabular}{|c|c|c|c|c|}
\hline Product & Seaweed Species & Claims & Active Ingredients & $\begin{array}{c}\text { Patent/Patent } \\
\text { Application nr }\end{array}$ \\
\hline $\begin{array}{l}\text { PhExt and } \\
\text { anti-inflammatory } \\
\text { composition }\end{array}$ & F. vesiculosus + A. nodosum & $\begin{array}{l}\text { Method for production extracts } \\
\text { with high content of } \\
\text { phlorotannins and further } \\
\text { production of an anti- } \\
\text { inflammatory composition } \\
\text { using these phlorotannin-rich } \\
\text { extracts as active ingredient for } \\
\text { application in medicaments for } \\
\text { treating allergies and arthritis }\end{array}$ & $\begin{array}{l}\text { Algal extract containing } \\
11 \%-19 \% \text { phlorotannins }\end{array}$ & FR2914190A1 [142] \\
\hline $\begin{array}{l}\text { Anti-inflammatory } \\
\text { composition }\end{array}$ & E. stolonifera and E. cava & $\begin{array}{l}\text { Production of a composition } \\
\text { containing E. stolonifera and } \\
\text { E. cava phlorotannin extracts or } \\
\text { isolated phlorotannins for } \\
\text { application in farmaceutical } \\
\text { formulations aiming the } \\
\text { inhibition of iNOS and COX-2 } \\
\text { on inflammatory- } \\
\text { related diseases }\end{array}$ & Phlorofucofuroeckol A & KR20120054577A [141] \\
\hline
\end{tabular}

Production of a composition containing phlorotannins from brown seaweeds with inhibitory effects against matrix metalloproteinases to be used in form of powders, tablets, capsules, ointment compositions, solutions, gels,
pastes, patches, granules for the

Anti-MMP composition treatment of wound, cancer metastasis, rheumatoid arthritis, inflammation,

hyperparathyroidism, diabetes, corneal ulcer, osteoporosis, stomach ulcer, acne, burn, periodontal diseases, arteriosclerosis and fracture

Production of a composition containing eckol isolated from E. cava capable of suppressing tumorigenesis, cancer growth, Anti-cancer composition E. cava invasion, metastasis and malignance in k-Ras expressing cancers via inhibition of the PI3K-Akt signaling and Ras signaling through Ras-Raf-ERK signal transduction system

Production of a composition containing eckol isolated from E. cava for prevention of cancer

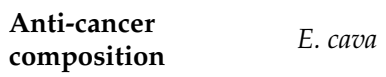
stem cell growth via suppression of the Ras signaling through the

transduction system

\section{Concluding Remarks}

In conclusion, the data herein gathered make it clear that brown algae phlorotannins and phlorotannin-rich extracts are unanimously acknowledged by their remarkable effects on critical steps involved in the pathogenesis of cancer, either directly acting as proapoptotic, anti-proliferative, anti-metastatic or antiangiogenic agents or indirectly through inhibition of the multiple mechanisms of the oxidative stress-inflammation network which are intimately linked to tumorigenesis. These compounds are, therefore, endowed with a high versatility and capacity to promote and improve health status by acting on different 
fronts, opening a path for possible innovations on different fields. In fact, some important steps have already been taken in this direction, which can be measured by the number of phlorotannin-related patents that have been slowly but steadily emerging over the last years, meaning that these compounds are indeed object of great economic interest. This strengthens the hypothesis that phlorotannins could be used as valuable naturally occurring pharmacological alternatives for the development of novel therapeutic strategies for treating not only cancer but also other diseases.

Author Contributions: M.D.C. contributed to conceptualization, literature review and writing the original draft; S.J.A. contributed to literature review and writing the original draft; N.M. and A.M.S.S. contributed to supervision and writing-reviewing and editing; S.M.C. contribution to conceptualization, supervision, writing - reviewing and editing, resources and project administration. All authors have read and agreed to the published version of the manuscript.

Funding: This research was funded by the European Union (FEDER funds through COMPETE POCI-01-0145-FEDER-031015) and National Funds (FCT, Fundação para a Ciência e Tecnologia) through project PTDC/BAA-AGR/31015/2017, "Algaphlor-Brown algae phlorotannins: From bioavailability to the development of new functional foods".

Acknowledgments: We would like to thank the support of the project UIDB/50006/2020 \& UIDP/ 50006/2020, funded by FCT/MCTES (FCT/MEC, Fundação para a Ciência e Tecnologia e Ministério da Educação e Ciência) through national funds. M.D.C. thanks for his PhD grant (PD/BD/114577/ 2016) which was funded by FCT (Fundação para a Ciência e Tecnologia) and ESF (European Social Fund) through POCH (Programa Operacional Capital Humano). S.M.C. acknowledges the research contract under the project PTDC/BAA-AGR/31015/2017 (Algaphlor).

Conflicts of Interest: The authors declare no conflict of interest. The funders had no role in the design of the study; in the collection, analyses, or interpretation of data; in the writing of the manuscript, or in the decision to publish the results.

\section{References}

1. Catarino, M.D.; Silva, A.M.S.; Cardoso, S.M. Phycochemical Constituents and Biological Activities of Fucus spp. Mar. Drugs 2018, 16, 249. [CrossRef] [PubMed]

2. Bocanegra, A.; Bastida, S.; Benedí, J.; Ródenas, S.; Sánchez-Muniz, F.J. Characteristics and nutritional and cardiovascular-health properties of seaweeds. J. Med. Food 2009, 12, 236-258. [CrossRef] [PubMed]

3. Stévant, P.; Rebours, C.; Chapman, A. Seaweed aquaculture in Norway: Recent industrial developments and future perspectives. Aquac. Int. 2017, 25, 1373-1390. [CrossRef]

4. Gomez-Zavaglia, A.; Prieto Lage, M.A.; Jimenez-Lopez, C.; Mejuto, J.C.; Simal-Gandara, J. The potential of seaweeds as a source of functional ingredients of prebiotic and antioxidant value. Antioxidants 2019, 8, 406. [CrossRef] [PubMed]

5. Isaza Martínez, J.H.; Torres Castañeda, H.G. Preparation and chromatographic analysis of phlorotannins. J. Chromatogr. Sci. 2013, 51, 825-838. [CrossRef] [PubMed]

6. Pal Singh, I.; Bharate, S.B. Phloroglucinol compounds of natural origin. Nat. Prod. Rep. 2006, 23, 558-591. [CrossRef] [PubMed]

7. Catarino, D.M.; Silva, M.A.; Cardoso, M.S. Fucaceae: A Source of Bioactive Phlorotannins. Int. J. Mol. Sci. 2017, 18, 1327. [CrossRef] [PubMed]

8. WHO Cancer. Available online: https://www.who.int/health-topics/cancer\#tab=tab_1 (accessed on 6 May 2021).

9. Ahn, G.-N.; Kim, K.-N.; Cha, S.-H.; Song, C.-B.; Lee, J.; Heo, M.-S.; Yeo, I.-K.; Lee, N.-H.; Jee, Y.-H.; Kim, J.-S.; et al. Antioxidant activities of phlorotannins purified from Ecklonia cava on free radical scavenging using ESR and $\mathrm{H}_{2} \mathrm{O}_{2}$-mediated DNA damage. Eur. Food Res. Technol. 2007, 226, 71-79. [CrossRef]

10. Catarino, M.D.; Silva, A.; Cruz, M.T.; Mateus, N.; Silva, A.M.S.; Cardoso, S.M. Phlorotannins from Fucus vesiculosus: Modulation of inflammatory response by blocking NF-кB signaling pathway. Int. J. Mol. Sci. 2020, 21, 6897. [CrossRef] [PubMed]

11. Rajauria, G.; Jaiswal, A.K.; Abu-Gannam, N.; Gupta, S. Antimicrobial, antioxidant and free radical-scavenging capacity of brown seaweed Himanthalia elongata from western coast of Ireland. J. Food Biochem. 2013, 37, 322-335. [CrossRef]

12. Nwosu, F.; Morris, J.; Lund, V.A.; Stewart, D.; Ross, H.A.; McDougall, G.J. Anti-proliferative and potential anti-diabetic effects of phenolic-rich extracts from edible marine algae. Food Chem. 2011, 126, 1006-1012. [CrossRef]

13. Khansari, N.; Shakiba, Y.; Mahmoudi, M. Chronic inflammation and oxidative stress as a major cause of age-related diseases and cancer. Recent Pat. Inflamm. Allergy Drug Discov. 2009, 3, 73-80. [CrossRef] [PubMed]

14. Dröge, W. Free radicals in the physiological control of cell function. Physiol. Rev. 2002, 82, 47-95. [CrossRef]

15. Balamurugan, K.; Karthikeyan, J. Evaluation of luteolin in the prevention of $N$-nitrosodiethylamine-induced hepatocellular carcinoma using animal model system. Indian J. Clin. Biochem. 2012, 27, 157-163. [CrossRef] [PubMed] 
16. Kruidenier, L.; Verspaget, H.W. Review article: Oxidative stress as a pathogenic factor in inflammatory bowel disease-Radicals or ridiculous? Aliment. Pharmacol. Ther. 2002, 16, 1997-2015. [CrossRef] [PubMed]

17. Catarino, M.D.; Alves-Silva, J.M.; Pereira, O.R.; Cardoso, S.M. Antioxidant Capacities of Flavones and Benefits in Oxidative-Stress Related Diseases. Curr. Top. Med. Chem. 2015, 15, 105-119. [CrossRef]

18. Kim, Y.J.; Kim, E.H.; Hahm, K.B. Oxidative stress in inflammation-based gastrointestinal tract diseases: Challenges and opportunities. J. Gastroenterol. Hepatol. 2012, 27, 1004-1010. [CrossRef] [PubMed]

19. Franco, R.; Schoneveld, O.; Georgakilas, A.G.; Panayiotidis, M.I. Oxidative stress, DNA methylation and carcinogenesis. Cancer Lett. 2008, 266, 6-11. [CrossRef] [PubMed]

20. Federico, A.; Morgillo, F.; Tuccillo, C.; Ciardiello, F.; Loguercio, C. Chronic inflammation and oxidative stress in human carcinogenesis. Int. J. Cancer 2007, 121, 2381-2386. [CrossRef]

21. Corden, J.L.; Tollervey, D. Programmed Cell Death. In Cell Biology; Pollard, T.D., Earnshaw, W.C., Lippincott-Schwartz, J., Johnson, G.T., Eds.; Elsevier: Amsterdam, The Netherlands, 2017; pp. 797-815. ISBN 978-0-323-34126-4.

22. Green, D.R.; Llambi, F. Cell death signaling. Cold Spring Harb. Perspect. Biol. 2015, 7, a006080. [CrossRef] [PubMed]

23. Duračková, Z. Some current insights into oxidative stress. Physiol. Res. 2010, 59, 459-469. [CrossRef] [PubMed]

24. Schwitalla, S.; Ziegler, P.K.; Horst, D.; Becker, V.; Kerle, I.; Begus-Nahrmann, Y.; Lechel, A.; Rudolph, K.L.; Langer, R.; SlottaHuspenina, J.; et al. Loss of p53 in Enterocytes Generates an Inflammatory Microenvironment Enabling Invasion and Lymph Node Metastasis of Carcinogen-Induced Colorectal Tumors. Cancer Cell 2013, 23, 93-106. [CrossRef]

25. Olivier, M.; Hollstein, M.; Hainaut, P. TP53 mutations in human cancers: Origins, consequences, and clinical use. Cold Spring Harb. Perspect. Biol. 2010, 2, a001008. [CrossRef]

26. García-Aranda, M.; Pérez-Ruiz, E.; Redondo, M. Bcl-2 inhibition to overcome resistance to chemo-and immunotherapy. Int. J. Mol. Sci. 2018, 19, 3950. [CrossRef] [PubMed]

27. Hanahan, D.; Weinberg, R.A. Hallmarks of cancer: The next generation. Cell 2011, 144, 646-674. [CrossRef]

28. Kang, M.-C.; Cha, S.H.; Wijesinghe, W.A.J.P.; Kang, S.-M.; Lee, S.-H.; Kim, E.-A.; Song, C.B.; Jeon, Y.-J. Protective effect of marine algae phlorotannins against AAPH-induced oxidative stress in zebrafish embryo. Food Chem. 2013, 138, 950-955. [CrossRef] [PubMed]

29. Ahn, B.R.; Moon, H.E.; Kim, H.R.; Jung, H.A.; Choi, J.S. Neuroprotective effect of edible brown alga Eisenia bicyclis on amyloid beta peptide-induced toxicity in PC12 cells. Arch. Pharm. Res. 2012, 35, 1989-1998. [CrossRef] [PubMed]

30. He, Y.-Q.; Zhang, W.-T.; Shi, C.-H.; Wang, F.-M.; Tian, X.-J.; Ma, L.-L. Phloroglucinol protects the urinary bladder via inhibition of oxidative stress and inflammation in a rat model of cyclophosphamide-induced interstitial cystitis. Chin. Med. J. 2015, 128, 956-962. [CrossRef]

31. Jun, Y.-J.; Lee, M.; Shin, T.; Yoon, N.; Kim, J.-H.; Kim, H.-R. Eckol enhances heme oxygenase-1 expression through activation of Nrf2/JNK pathway in HepG2 Cells. Molecules 2014, 19, 15638-15652. [CrossRef]

32. Lee, M.S.; Lee, B.; Park, K.E.; Utsuki, T.; Shin, T.; Oh, C.W.; Kim, H.R. Dieckol enhances the expression of antioxidant and detoxifying enzymes by the activation of Nrf2-MAPK signalling pathway in HepG2 cells. Food Chem. 2015, 174, 538-546. [CrossRef] [PubMed]

33. Kang, M.C.; Wijesinghe, W.A.J.P.; Lee, S.H.; Kang, S.M.; Ko, S.C.; Yang, X.; Kang, N.; Jeon, B.T.; Kim, J.; Lee, D.H.; et al. Dieckol isolated from brown seaweed Ecklonia cava attenuates type II diabetes in $d b / d b$ mouse model. Food Chem. Toxicol. 2013, 53, 294-298. [CrossRef]

34. Li, Y.; Qian, Z.-J.; Ryu, B.; Lee, S.-H.; Kim, M.-M.; Kim, S.-K. Chemical components and its antioxidant properties in vitro: An edible marine brown alga, Ecklonia cava. Bioorgan. Med. Chem. 2009, 17, 1963-1973. [CrossRef]

35. Kim, E.-A.; Kang, M.-C.; Lee, J.-H.; Kang, N.; Lee, W.; Oh, J.-Y.; Yang, H.-W.; Lee, J.-S.; Jeon, Y.-J. Protective effect of marine brown algal polyphenols against oxidative stressed zebrafish with high glucose. RSC Adv. 2015, 5, 25738-25746. [CrossRef]

36. Lee, M.-S.; Shin, T.; Utsuki, T.; Choi, J.-S.; Byun, D.-S.; Kim, H.-R. Isolation and identification of phlorotannins from Ecklonia stolonifera with antioxidant and hepatoprotective properties in tacrine-treated HepG2 cells. J. Agric. Food Chem. 2012, 60, 5340-5349. [CrossRef] [PubMed]

37. Casas, M.P.; Rodríguez-Hermida, V.; Pérez-Larrán, P.; Conde, E.; Liveri, M.T.; Ribeiro, D.; Fernandes, E.; Domínguez, H. In vitro bioactive properties of phlorotannins recovered from hydrothermal treatment of Sargassum muticum. Sep. Purif. Technol. 2016, 167, 117-126. [CrossRef]

38. Kim, A.-R.; Shin, T.-S.; Lee, M.-S.; Park, J.-Y.; Park, K.-E.; Yoon, N.-Y.; Kim, J.-S.; Choi, J.-S.; Jang, B.-C.; Byun, D.-S.; et al. Isolation and identification of phlorotannins from Ecklonia stolonifera with antioxidant and anti-inflammatory properties. J. Agric. Food Chem. 2009, 57, 3483-3489. [CrossRef] [PubMed]

39. Liu, X.; Yuan, W.; Sharma-shivappa, R.; Zanten, J. Van Antioxidant activity of phlorotannins from brown algae. Int. J. Agric. Biol. Eng. 2017, 10, 184-191. [CrossRef]

40. Wang, T.; Jónsdóttir, R.; Liu, H.; Gu, L.; Kristinsson, H.G.; Raghavan, S.; Ólafsdóttir, G. Antioxidant capacities of phlorotannins extracted from the brown algae Fucus vesiculosus. J. Agric. Food Chem. 2012, 60, 5874-5883. [CrossRef] [PubMed]

41. Nakai, M.; Kageyama, N.; Nakahara, K.; Miki, W. Phlorotannins as radical scavengers from the extract of Sargassum ringgoldianum. Mar. Biotechnol. 2006, 8, 409-414. [CrossRef] [PubMed]

42. Shibata, T.; Ishimaru, K.; Kawaguchi, S.; Yoshikawa, H.; Hama, Y. Antioxidant activities of phlorotannins isolated from Japanese Laminariaceae. J. Appl. Phycol. 2008, 20, 705-711. [CrossRef] 
43. Zaragozá, M.C.; López, D.; Sáiz, M.P.; Poquet, M.; Pérez, J.; Puig-Parellada, P.; Màrmol, F.; Simonetti, P.; Gardana, C.; Lerat, Y.; et al. Toxicity and antioxidant activity in vitro and in vivo of two Fucus vesiculosus extracts. J. Agric. Food Chem. 2008, 56, 7773-7780. [CrossRef] [PubMed]

44. Dutot, M.; Fagon, R.; Hemon, M.; Rat, P. Antioxidant, anti-inflammatory, and anti-senescence activities of a phlorotannin-rich natural extract from Brown Seaweed Ascophyllum nodosum. Appl. Biochem. Biotechnol. 2012, 167, 2234-2240. [CrossRef] [PubMed]

45. Quéguineur, B.; Goya, L.; Ramos, S.; Martín, M.A.; Mateos, R.; Guiry, M.D.; Bravo, L. Effect of phlorotannin-rich extracts of Ascophyllum nodosum and Himanthalia elongata (Phaeophyceae) on cellular oxidative markers in human HepG2 cells. J. Appl. Phycol. 2013, 25, 1-11. [CrossRef]

46. Lee, S.; Youn, K.; Kim, D.H.; Ahn, M.R.; Yoon, E.; Kim, O.Y.; Jun, M. Anti-Neuroinflammatory Property of Phlorotannins from Ecklonia cava on A $\beta_{25-35}$-Induced Damage in PC12 Cells. Mar. Drugs 2019, 17, 7. [CrossRef]

47. Lee, J.H.; Ko, J.Y.; Oh, J.Y.; Kim, E.A.; Kim, C.Y.; Jeon, Y.J. Evaluation of phlorofucofuroeckol-A isolated from Ecklonia cava (Phaeophyta) on anti-lipid peroxidation in vitro and in vivo. Algae 2015, 30, 313-323. [CrossRef]

48. Kim, K.C.; Piao, M.J.; Cho, S.J.; Lee, N.H.; Hyun, J.W. Phloroglucinol protects human keratinocytes from ultraviolet B radiation by attenuating oxidative stress. Photodermatol. Photoimmunol. Photomed. 2012, 28, 322-331. [CrossRef] [PubMed]

49. Jang, J.; Ye, B.-R.; Heo, S.-J.; Oh, C.; Kang, D.-H.; Kim, J.H.; Affan, A.; Yoon, K.-T.; Choi, Y.-U.; Park, S.C.; et al. Photo-oxidative stress by ultraviolet-B radiation and antioxidative defense of eckstolonol in human keratinocytes. Environ. Toxicol. Pharmacol. 2012, 34, 926-934. [CrossRef] [PubMed]

50. O'Sullivan, A.M.; O'Callaghan, Y.C.; O'Grady, M.N.; Hayes, M.; Kerry, J.P.; O'Brien, N.M. The effect of solvents on the antioxidant activity in Caco-2 cells of Irish brown seaweed extracts prepared using accelerated solvent extraction (ASE ${ }^{\circledR}$ ). J. Funct. Foods 2013, 5, 940-948. [CrossRef]

51. O'Sullivan, A.M.; O'Callaghan, Y.C.; O'Grady, M.N.; Queguineur, B.; Hanniffy, D.; Troy, D.J.; Kerry, J.P.; O’Brien, N.M. In vitro and cellular antioxidant activities of seaweed extracts prepared from five brown seaweeds harvested in spring from the west coast of Ireland. Food Chem. 2011, 126, 1064-1070. [CrossRef]

52. O'Sullivan, A.M.; O'Callaghan, Y.C.; O'Grady, M.N.; Queguineur, B.; Hanniffy, D.; Troy, D.J.; Kerry, J.P.; O’Brien, N.M. Assessment of the ability of seaweed extracts to protect against hydrogen peroxide and tert-butyl hydroperoxide induced cellular damage in Caco-2 cells. Food Chem. 2012, 134, 1137-1140. [CrossRef]

53. Corona, G.; Coman, M.M.; Guo, Y.; Hotchkiss, S.; Gill, C.; Yaqoob, P.; Spencer, J.P.E.; Rowland, I. Effect of simulated gastrointestinal digestion and fermentation on polyphenolic content and bioactivity of brown seaweed phlorotannin-rich extracts. Mol. Nutr. Food Res. 2017, 61. [CrossRef]

54. Kim, M.M.; Kim, S.K. Effect of phloroglucinol on oxidative stress and inflammation. Food Chem. Toxicol. 2010, 48, 2925-2933. [CrossRef]

55. Kang, S.M.; Heo, S.J.; Kim, K.N.; Lee, S.H.; Jeon, Y.J. Isolation and identification of new compound, 2,7'-phloroglucinol-6,6'-bieckol from brown algae, Ecklonia cava and its antioxidant effect. J. Funct. Foods 2012, 4, 158-166. [CrossRef]

56. Zou, Y.; Qian, Z.-J.; Li, Y.; Kim, M.-M.; Lee, S.-H.; Kim, S.-K. Antioxidant effects of phlorotannins isolated from Ishige okamurae in free radical mediated oxidative systems. J. Agric. Food Chem. 2008, 56, 7001-7009. [CrossRef] [PubMed]

57. Guinea, M.; Franco, V.; Araujo-Bazán, L.; Rodríguez-Martín, I.; González, S. In vivo UVB-photoprotective activity of extracts from commercial marine macroalgae. Food Chem. Toxicol. 2012, 50, 1109-1117. [CrossRef]

58. Kang, M.C.; Kim, K.N.; Kang, S.M.; Yang, X.; Kim, E.A.; Song, C.B.; Nah, J.W.; Jang, M.K.; Lee, J.S.; Jung, W.K.; et al. Protective effect of dieckol isolated from Ecklonia cava against ethanol caused damage in vitro and in zebrafish model. Environ. Toxicol. Pharmacol. 2013, 36, 1217-1226. [CrossRef]

59. Ko, S.-C.; Cha, S.-H.; Heo, S.-J.; Lee, S.-H.; Kang, S.-M.; Jeon, Y.-J. Protective effect of Ecklonia cava on UVB-induced oxidative stress: In Vitro and in vivo zebrafish model. J. Appl. Phycol. 2011, 23, 697-708. [CrossRef]

60. Wei, Y.; Li, Z.; Hu, Y.; Xu, Z. Inhibition of mouse liver lipid peroxidation by high molecular weight phlorotannins from Sargassum kjellmanianum. J. Appl. Phycol. 2003, 15, 507-511. [CrossRef]

61. Sprygin, V.G.; Kushnerova, N.F.; Fomenko, S.E.; Drugova, E.S.; Lesnikova, L.N.; Merzlyakov, V.Y.; Momot, T.V. The Influence of an Extract from the Marine Brown Alga Sargassum pallidum on the Metabolic Reactions in the Liver under Experimental Toxic Hepatitis. Russ. J. Mar. Biol. 2017, 43, 479-484. [CrossRef]

62. Baldrick, F.R.; McFadden, K.; Ibars, M.; Sung, C.; Moffatt, T.; Megarry, K.; Thomas, K.; Mitchell, P.; Wallace, J.M.W.; Pourshahidi, L.K.; et al. Impact of a (poly)phenol-rich extract from the brown algae Ascophyllum nodosum on DNA damage and antioxidant activity in an overweight or obese population: A randomized controlled trial. Am. J. Clin. Nutr. 2018, 108, 688-700. [CrossRef]

63. Schultz Moreira, A.R.; Benedí, J.; González-Torres, L.; Olivero-David, R.; Bastida, S.; Sánchez-Reus, M.I.; González-Muñoz, M.J.; Sánchez-Muniz, F.J. Effects of diet enriched with restructured meats, containing Himanthalia elongata, on hypercholesterolaemic induction, CYP7A1 expression and antioxidant enzyme activity and expression in growing rats. Food Chem. 2011, 129, 1623-1630. [CrossRef]

64. Jin, D.Q.; Li, G.; Kim, J.S.; Yong, C.S.; Kim, J.A.; Huh, K. Preventive effects of Laminaria japonica aqueous extract on the oxidative stress and xanthine oxidase activity in streptozotocin-induced diabetic rat liver. Biol. Pharm. Bull. 2004, 27, 1037-1040. [CrossRef] 
65. Sadeeshkumar, V.; Duraikannu, A.; Aishwarya, T.; Jayaram, P.; Ravichandran, S.; Ganeshamurthy, R. Radioprotective efficacy of dieckol against gamma radiation-induced cellular damage in hepatocyte cells. Naunyn Schmiedeberg's Arch. Pharmacol. 2019, 392, 1031-1041. [CrossRef] [PubMed]

66. Kang, M.C.; Kang, S.M.; Ahn, G.; Kim, K.N.; Kang, N.; Samarakoon, K.W.; Oh, M.C.; Lee, J.S.; Jeon, Y.J. Protective effect of a marine polyphenol, dieckol against carbon tetrachloride-induced acute liver damage in mouse. Environ. Toxicol. Pharmacol. 2013, 35, 517-523. [CrossRef]

67. Li, S.; Liu, J.; Zhang, M.; Chen, Y.; Zhu, T.; Wang, J. Protective Effect of Eckol against Acute Hepatic injury Induced by Carbon Tetrachloride in Mice. Mar. Drugs 2018, 16, 300. [CrossRef] [PubMed]

68. Kim, A.D.; Kang, K.A.; Piao, M.J.; Kim, K.C.; Zheng, J.; Yao, C.W.; Cha, J.W.; Hyun, C.L.; Kang, H.K.; Lee, N.H.; et al. Cytoprotective effect of eckol against oxidative stress-induced mitochondrial dysfunction: Involvement of the FoxO3a/AMPK pathway. J. Cell. Biochem. 2014, 115, 1403-1411. [CrossRef] [PubMed]

69. Kang, K.A.; Lee, K.H.; Chae, S.; Zhang, R.; Jung, M.S.; Ham, Y.M.; Baik, J.S.; Lee, N.H.; Hyun, J.W. Cytoprotective effect of phloroglucinol on oxidative stress induced cell damage via catalase activation. J. Cell. Biochem. 2006, 97, 609-620. [CrossRef] [PubMed]

70. Kang, K.A.; Lee, K.H.; Chae, S.; Koh, Y.S.; Yoo, B.S.; Kim, J.H.; Ham, Y.M.; Baik, J.S.; Lee, N.H.; Hyun, J.W. Triphlorethol-A from Ecklonia cava protects V79-4 lung fibroblast against hydrogen peroxide induced cell damage. Free Radic. Res. 2005, 39, 883-892. [CrossRef]

71. Yokogawa, K.; Matsui-Yuasa, I.; Tamura, A.; Terada, M.; Kojima-Yuasa, A. Inhibitory effects of Ecklonia cava extract on high glucose-induced hepatic stellate cell activation. Mar. Drugs 2011, 9, 2783-2808. [CrossRef]

72. Quéguineur, B.; Goya, L.; Ramos, S.; Martín, M.A.; Mateos, R.; Bravo, L. Phloroglucinol: Antioxidant properties and effects on cellular oxidative markers in human HepG2 cell line. Food Chem. Toxicol. 2012, 50, 2886-2893. [CrossRef]

73. Ma, Q. Role of Nrf2 in oxidative stress and toxicity. Annu. Rev. Pharmacol. Toxicol. 2013, 53, 401-426. [CrossRef] [PubMed]

74. Kim, K.C.; Kang, K.A.; Zhang, R.; Piao, M.J.; Kim, G.Y.; Kang, M.Y.; Lee, S.J.; Lee, N.H.; Surh, Y.J.; Hyun, J.W. Up-regulation of Nrf2-mediated heme oxygenase-1 expression by eckol, a phlorotannin compound, through activation of Erk and PI3K/Akt. Int. J. Biochem. Cell Biol. 2010, 42, 297-305. [CrossRef] [PubMed]

75. Yang, E.-J.; Ahn, S.; Ryu, J.; Choi, M.-S.; Choi, S.; Chong, Y.H.; Hyun, J.-W.; Chang, M.-J.; Kim, H.-S. Phloroglucinol attenuates motor functional deficits in an animal model of Parkinson's disease by enhancing Nrf2 activity. PLoS ONE 2013, 8, e71178. [CrossRef]

76. Moon, H.E.; Ahn, B.R.; Jung, H.A.; Choi, J.S. Inhibitory activity of Ecklonia stolonifera and its isolated phlorotannins against $\mathrm{Cu}^{2+}$-induced low-density lipoprotein oxidation. Fish. Sci. 2012, 78, 927-934. [CrossRef]

77. Shin, H.C.; Hwang, H.J.; Kang, K.J.; Lee, B.H. An antioxidative and antiinflammatory agent for potential treatment of osteoarthritis from Ecklonia cava. Arch. Pharm. Res. 2006, 29, 165-171. [CrossRef] [PubMed]

78. Venkatesan, J.; Keekan, K.K.; Anil, S.; Bhatnagar, I.; Kim, S.K. Phlorotannins. Encycl. Food Chem. 2018, 3, 515-527. [CrossRef]

79. Kim, T.H.; Ku, S.-K.; Lee, T.; Bae, J.-S. Vascular barrier protective effects of phlorotannins on HMGB1-mediated proinflammatory responses in vitro and in vivo. Food Chem. Toxicol. 2012, 50, 2188-2195. [CrossRef] [PubMed]

80. Kang, Y.-M.; Eom, S.-H.; Kim, Y.-M. Protective effect of phlorotannins from Eisenia bicyclis against lipopolysaccharide-stimulated inflammation in HepG2 cells. Environ. Toxicol. Pharmacol. 2013, 35, 395-401. [CrossRef]

81. Jung, W.-K.; Heo, S.-J.; Jeon, Y.-J.; Lee, C.-M.; Park, Y.-M.; Byun, H.-G.; Choi, Y.H.; Park, S.-G.; Choi, I.-W. Inhibitory effects and molecular mechanism of dieckol isolated from marine brown alga on COX-2 and iNOS in microglial cells. J. Agric. Food Chem. 2009, 57, 4439-4446. [CrossRef]

82. Paudel, U.; Lee, Y.H.; Kwon, T.H.; Park, N.H.; Yun, B.S.; Hwang, P.H.; Yi, H.K. Eckols reduce dental pulp inflammation through the ERK1/2 pathway independent of COX-2 inhibition. Oral Dis. 2014, 20, 827-832. [CrossRef] [PubMed]

83. Kim, S.; Choi, S.; Kim, G.; Imm, J. Anti-Inflammatory Effect of Ecklonia cava Extract on Porphyromonas gingivalis LipopolysaccharideStimulated Macrophages and a Periodontitis Rat Model. Nutrients 2019, 11, 1143. [CrossRef]

84. Jung, W.K.; Ahn, Y.W.; Lee, S.H.; Choi, Y.H.; Kim, S.K.; Yea, S.S.; Choi, I.; Park, S.G.; Seo, S.K.; Lee, S.W.; et al. Ecklonia cava ethanolic extracts inhibit lipopolysaccharide-induced cyclooxygenase-2 and inducible nitric oxide synthase expression in BV2 microglia via the MAP kinase and NF-кB pathways. Food Chem. Toxicol. 2008, 47, 410-417. [CrossRef] [PubMed]

85. Yang, E.J.; Ham, Y.M.; Kim, D.S.; Kim, J.Y.; Hong, J.P.; Kim, M.J.; Moon, J.Y.; Lee, W.J.; Lee, N.H.; Hyun, C.G. Ecklonia stolonifera inhibits lipopolysaccharide-induced production of nitric oxide, prostaglandin E2, and proinflammatory cytokines in RAW264.7 macrophages. Biologia 2010, 65, 362-371. [CrossRef]

86. Lee, M.-S.; Kwon, M.-S.; Choi, J.-W.; Shin, T.; No, H.-K.; Choi, J.-S.; Byun, D.-S.; Kim, J.-I.; Kim, H.-R. Anti-inflammatory activities of an ethanol extract of Ecklonia stolonifera in lipopolysaccharide-stimulated RAW 264.7 murine macrophage cells. J. Agric. Food Chem. 2012, 60, 9120-9129. [CrossRef]

87. Tenorio-Rodríguez, P.A.; Esquivel-Solis, H.; Murillo-Álvarez, J.I.; Ascencio, F.; Campa-Córdova, Á.I.; Angulo, C. Biosprospecting potential of kelp (Laminariales, Phaeophyceae) from Baja California Peninsula: Phenolic content, antioxidant properties, antiinflammatory, and cell viability. J. Appl. Phycol. 2019, 31, 3115-3129. [CrossRef]

88. Lee, S.-H.; Eom, S.-H.; Yoon, N.-Y.; Kim, M.-M.; Li, Y.-X.; Ha, S.K.; Kim, S.-K. Fucofuroeckol-A from Eisenia bicyclis Inhibits Inflammation in Lipopolysaccharide-Induced Mouse Macrophages via Downregulation of the MAPK/NF-kappa B Signaling Pathway. J. Chem. 2016, 2016, 6509212. [CrossRef] 
89. Yang, Y.-I.; Shin, H.-C.; Kim, S.H.; Park, W.-Y.; Lee, K.-T.; Choi, J.-H. 6,6'-Bieckol, isolated from marine alga Ecklonia cava, suppressed LPS-induced nitric oxide and PGE 2 production and inflammatory cytokine expression in macrophages: The inhibition of NFkB. Int. Immunopharmacol. 2012, 12, 510-517. [CrossRef] [PubMed]

90. Barbosa, M.; Lopes, G.; Ferreres, F.; Andrade, P.B.; Pereira, D.M.; Gil-Izquierdo, Á.; Valentão, P. Phlorotannin extracts from Fucales: Marine polyphenols as bioregulators engaged in inflammation-related mediators and enzymes. Algal Res. 2017, 28, 1-8. [CrossRef]

91. Kim, M.E.; Jung, Y.C.; Jung, I.; Lee, H.W.; Youn, H.Y.; Lee, J.S. Anti-inflammatory effects of ethanolic extract from Sargassum horneri (Turner) C. Agardh on lipopolysaccharide-stimulated macrophage activation via NF-kB pathway regulation. Immunol. Investig. 2015, 44, 137-146. [CrossRef] [PubMed]

92. Kim, M.J.; Kim, K.B.W.R.; Jeong, D.H.; Ahn, D.H. Anti-inflammatory activity of ethanolic extract of Sargassum sagamianum in RAW 264.7 cells. Food Sci. Biotechnol. 2013, 22, 1113-1120. [CrossRef]

93. Kim, K.N.; Kim, J.; Yoon, W.J.; Yang, H.M.; Heo, S.Y.; Ko, J.Y.; Roh, S.W.; Jeon, Y.J.; Kang, S.M.; Heo, S.J.; et al. Inhibitory effect of Sargassum patens on inflammation and melanogenesis. Int. J. Pharmacol. 2013, 9, 524-532. [CrossRef]

94. Lee, C.; Park, G.H.; Ahn, E.M.; Park, C.I.; Jang, J.H. Sargassum fulvellum protects HaCaT cells and BALB/c mice from UVB-induced proinflammatory responses. Evid. Based Complement. Altern. Med. 2013, 2013, 747846. [CrossRef]

95. Yayeh, T.; Im, E.J.; Kwon, T.H.; Roh, S.S.; Kim, S.; Kim, J.H.; Hong, S.B.; Cho, J.Y.; Park, N.H.; Rhee, M.H. Hemeoxygenase 1 partly mediates the anti-inflammatory effect of dieckol in lipopolysaccharide stimulated murine macrophages. Int. Immunopharmacol. 2014, 22, 51-58. [CrossRef] [PubMed]

96. Kim, A.-R.; Lee, M.-S.; Shin, T.-S.; Hua, H.; Jang, B.-C.; Choi, J.-S.; Byun, D.-S.; Utsuki, T.; Ingram, D.; Kim, H.-R. Phlorofucofuroeckol A inhibits the LPS-stimulated iNOS and COX-2 expressions in macrophages via inhibition of NF- $\mathrm{kB}$, Akt, and p38 MAPK. Toxicol. In Vitro 2011, 25, 1789-1795. [CrossRef] [PubMed]

97. Kim, A.R.; Lee, B.; Joung, E.J.; Gwon, W.G.; Utsuki, T.; Kim, N.G.; Kim, H.R. 6,6'-Bieckol suppresses inflammatory responses by down-regulating nuclear factor- $\mathrm{kB}$ activation via Akt, JNK, and p38 MAPK in LPS-stimulated microglial cells. Immunopharmacol. Immunotoxicol. 2016, 38, 244-252. [CrossRef] [PubMed]

98. Abdelhamid, A.; Jouini, M.; Bel Haj Amor, H.; Mzoughi, Z.; Dridi, M.; Ben Said, R.; Bouraoui, A. Phytochemical Analysis and Evaluation of the Antioxidant, Anti-Inflammatory, and Antinociceptive Potential of Phlorotannin-Rich Fractions from Three Mediterranean Brown Seaweeds. Mar. Biotechnol. 2018, 20, 60-74. [CrossRef]

99. Sanjeewa, K.K.A.; Jayawardena, T.U.; Lee, H.G.; Herath, K.H.I.N.M.; Jee, Y.; Jeon, Y.J. The protective effect of Sargassum horneri against particulate matter-induced inflammation in lung tissues of an in vivo mouse asthma model. Food Funct. 2019, 10, 7995-8004. [CrossRef] [PubMed]

100. Joung, E.J.; Lee, M.S.; Choi, J.W.; Kim, J.S.; Shin, T.; Jung, B.M.; Yoon, N.Y.; Lim, C.W.; Kim, J.I.; Kim, H.R. Anti-inflammatory effect of ethanolic extract from Myagropsis myagroides on murine macrophages and mouse ear edema. BMC Complement. Altern. Med. 2012, 12, 171. [CrossRef]

101. Yang, Y.I.; Woo, J.H.; Seo, Y.J.; Lee, K.T.; Lim, Y.; Choi, J.H. Protective Effect of Brown Alga Phlorotannins against Hyperinflammatory Responses in Lipopolysaccharide-Induced Sepsis Models. J. Agric. Food Chem. 2016, 64, 570-578. [CrossRef]

102. Corona, G.; Ji, Y.; Anegboonlap, P.; Hotchkiss, S.; Gill, C.; Yaqoob, P.; Spencer, J.P.E.; Rowland, I. Gastrointestinal modifications and bioavailability of brown seaweed phlorotannins and effects on inflammatory markers. Br. J. Nutr. 2016, 15, 1240-1253. [CrossRef]

103. Sugiura, Y.; Usui, M.; Katsuzaki, H.; Imai, K.; Miyata, M. Anti-inflammatory effects of 6,6'-bieckol and 6,8'-bieckol from Eisenia arborea on mouse ear swelling. Food Sci. Technol. Res. 2017, 23, 475-480. [CrossRef]

104. Sugiura, Y.; Usui, M.; Katsuzaki, H.; Imai, K.; Kakinuma, M.; Amano, H.; Miyata, M. Orally Administered Phlorotannins from Eisenia arborea Suppress Chemical Mediator Release and Cyclooxygenase-2 Signaling to Alleviate Mouse Ear Swelling. Mar. Drugs 2018, 16, 267. [CrossRef] [PubMed]

105. Sugiura, Y.; Tanaka, R.; Katsuzaki, H.; Imai, K.; Matsushita, T. The anti-inflammatory effects of phlorotannins from Eisenia arborea on mouse ear edema by inflammatory inducers. J. Funct. Foods 2013, 5, 2019-2023. [CrossRef]

106. Jeon, Y.J.; Kim, H.S.; Song, K.S.; Han, H.J.; Park, S.H.; Chang, W.; Lee, M.Y. Protective effect of dieckol against chemical hypoxia-induced cytotoxicity in primary cultured mouse hepatocytes. Drug Chem. Toxicol. 2015, 38, 180-187. [CrossRef]

107. Cha, S.H.; Ko, C.I.; Kim, D.; Jeon, Y.J. Protective effects of phlorotannins against ultraviolet B radiation in zebrafish (Danio rerio). Vet. Dermatol. 2012, 23, 51-e12. [CrossRef]

108. Lee, S.Y.; Lee, J.; Lee, H.; Kim, B.; Lew, J.; Baek, N.; Kim, S.-H. MicroRNA134 Mediated Upregulation of JNK and Downregulation of NFkB Signalings Are Critically Involved in Dieckol Induced Antihepatic Fibrosis. J. Agric. Food Chem. 2016, 64, 5508-5514. [CrossRef] [PubMed]

109. Kong, C.S.; Kim, J.A.; Ahn, B.N.; Kim, S.K. Potential effect of phloroglucinol derivatives from Ecklonia cava on matrix metalloproteinase expression and the inflammatory profile in lipopolysaccharide-stimulated human THP-1 macrophages. Fish. Sci. 2011, 77, 867-873. [CrossRef]

110. Lee, S.-H.; Han, J.-S.; Heo, S.-J.; Hwang, J.-Y.; Jeon, Y.-J. Protective effects of dieckol isolated from Ecklonia cava against high glucose-induced oxidative stress in human umbilical vein endothelial cells. Toxicol. In Vitro 2010, 24, 375-381. [CrossRef] [PubMed] 
111. Ryu, B.; Li, Y.; Qian, Z.J.; Kim, M.M.; Kim, S.K. Differentiation of human osteosarcoma cells by isolated phlorotannins is subtly linked to COX-2, iNOS, MMPs, and MAPK signaling: Implication for chronic articular disease. Chem. Biol. Interact. 2009, 179, 192-201. [CrossRef]

112. Yang, Y.I.; Jung, S.H.; Lee, K.T.; Choi, J.H. 8,8'-Bieckol, isolated from edible brown algae, exerts its anti-inflammatory effects through inhibition of NF-kB signaling and ROS production in LPS-stimulated macrophages. Int. Immunopharmacol. 2014, 23, 460-468. [CrossRef]

113. Mhadhebi, L.; Mhadhebi, A.; Robert, J.; Bouraoui, A. Antioxidant, anti-inflammatory and antiproliferative effects of aqueous extracts of three mediterranean brown seaweeds of the Genus Cystoseira. Iran. J. Pharm. Res. 2014, 13, 207-220. [CrossRef]

114. Ahn, J.H.; Yang, Y.I.; Lee, K.T.; Choi, J.H. Dieckol, isolated from the edible brown algae Ecklonia cava, induces apoptosis of ovarian cancer cells and inhibits tumor xenograft growth. J. Cancer Res. Clin. Oncol. 2014, 141, 255-268. [CrossRef] [PubMed]

115. He, Z.; Chen, Y.; Chen, Y.; Liu, H.; Yuan, G.; Fan, Y.; Chen, K. Optimization of the microwave-assisted extraction of phlorotannins from Saccharina japonica Aresch and evaluation of the inhibitory effects of phlorotannin-containing extracts on HepG2 cancer cells. Chin. J. Oceanol. Limnol. 2013, 31, 1045-1054. [CrossRef]

116. Abdelhamid, A.; Lajili, S.; Elkaibi, M.A.; Ben Salem, Y.; Abdelhamid, A.; Muller, C.D.; Majdoub, H.; Kraiem, J.; Bouraoui, A. Optimized Extraction, Preliminary Characterization and Evaluation of the In Vitro Anticancer Activity of Phlorotannin-Rich Fraction from the Brown Seaweed, Cystoseira sedoides. J. Aquat. Food Prod. Technol. 2019, 28, 892-909. [CrossRef]

117. Imbs, T.; Krasovskaya, N.; Ermakova, S.; Makarieva, T.; Shevchenko, N.; Zvyagintseva, T. Comparative study of chemical composition and antitumor activity of aqueous-ethanol extracts of brown algae Laminaria cichorioides, Costaria costata, and Fucus evanescens. Russ. J. Mar. Biol. 2009, 35, 164-170. [CrossRef]

118. Yuan, Y.V.; Walsh, N.A. Antioxidant and antiproliferative activities of extracts from a variety of edible seaweeds. Food Chem. Toxicol. 2006, 44, 1144-1150. [CrossRef]

119. Montero, L.; Sánchez-Camargo, A.P.; García-Cañas, V.; Tanniou, A.; Stiger-Pouvreau, V.; Russo, M.; Rastrelli, L.; Cifuentes, A.; Herrero, M.; Ibáñez, E. Anti-proliferative activity and chemical characterization by comprehensive two-dimensional liquid chromatography coupled to mass spectrometry of phlorotannins from the brown macroalga Sargassum muticum collected on North-Atlantic coasts. J. Chromatogr. A 2016, 1428, 115-125. [CrossRef] [PubMed]

120. Geisen, U.; Zenthoefer, M.; Peipp, M.; Kerber, J.; Plenge, J.; Managò, A.; Fuhrmann, M.; Geyer, R.; Hennig, S.; Adam, D.; et al. Molecular mechanisms by which a Fucus vesiculosus extract mediates cell cycle inhibition and cell death in pancreatic cancer cells. Mar. Drugs 2015, 13, 4470-4491. [CrossRef] [PubMed]

121. Lee, H.; Kang, C.; Jung, E.S.; Kim, J.S.; Kim, E. Antimetastatic activity of polyphenol-rich extract of Ecklonia cava through the inhibition of the Akt pathway in A549 human lung cancer cells. Food Chem. 2011, 127, 1229-1236. [CrossRef]

122. Kim, M.M.; Van Ta, Q.; Mendis, E.; Rajapakse, N.; Jung, W.K.; Byun, H.G.; Jeon, Y.J.; Kim, S.K. Phlorotannins in Ecklonia cava extract inhibit matrix metalloproteinase activity. Life Sci. 2006, 79, 1436-1443. [CrossRef]

123. Karadeniz, F.; Lee, S.G.; Oh, J.H.; Yu, G.H.; Jang, M.S.; Seo, Y.; Kong, C.S. Solvent-partitioned fractions from Ishige okamurae extract inhibit MMP-2 and MMP-9 activities in human fibrosarcoma cells in vitro. J. Appl. Phycol. 2018, 30, 121-127. [CrossRef]

124. Zhang, C.; Li, Y.; Shi, X.; Kim, S.K. Inhibition of the expression on MMP-2, 9 and morphological changes via human fibrosarcoma cell line by 6,6'-bieckol from marine alga Ecklonia cava. BMB Rep. 2010, 43, 62-68. [CrossRef] [PubMed]

125. Wang, C.H.; Li, X.F.; Jin, L.F.; Zhao, Y.; Zhu, G.J.; Shen, W.Z. Dieckol inhibits non-small-cell lung cancer cell proliferation and migration by regulating the PI3K/AKT signaling pathway. J. Biochem. Mol. Toxicol. 2019, 33, e22346. [CrossRef] [PubMed]

126. Sadeeshkumar, V.; Duraikannu, A.; Ravichandran, S. Modulatory efficacy of dieckol on xenobiotic-metabolizing enzymes, cell proliferation, apoptosis, invasion and angiogenesis during NDEA-induced rat hepatocarcinogenesis. Mol. Cell. Biochem. 2017, 433, 195-204. [CrossRef] [PubMed]

127. Kim, E.K.; Tang, Y.; Kim, Y.S.; Hwang, J.W.; Choi, E.J.; Lee, J.H.; Lee, S.H.; Jeon, Y.U.J.; Park, P.J. First evidence that Ecklonia cavaderived dieckol attenuates MCF-7 human breast carcinoma cell migration. Mar. Drugs 2015, 13, 1785-1797. [CrossRef] [PubMed]

128. Oh, S.-M.; Park, C.G.; Kang, J.H.; Kim, E.-J.; Chee, H.Y.; Lee, B.H.; Lee, K.B. Dieckol inhibits 12-O-tetradecanoylphorbol-13acetate-induced SK-Hep1 human hepatoma cell motility through suppression of matrix metalloproteinase-9 activity. J. Korean Soc. Appl. Biol. Chem. 2011, 54, 376-381. [CrossRef]

129. Lee, Y.J.; Park, J.H.; Park, S.A.; Joo, N.R.; Lee, B.H.; Lee, K.B.; Oh, S.M. Dieckol or phlorofucofuroeckol extracted from Ecklonia cava suppresses lipopolysaccharide-mediated human breast cancer cell migration and invasion. J. Appl. Phycol. 2020, 32, 631-640. [CrossRef]

130. Yoon, J.S.; Kasin Yadunandam, A.; Kim, S.J.; Woo, H.C.; Kim, H.R.; Kim, G.D. Dieckol, isolated from Ecklonia stolonifera, induces apoptosis in human hepatocellular carcinoma Hep3B cells. J. Nat. Med. 2013, 67, 519-527. [CrossRef]

131. Zhang, M.Y.; Guo, J.; Hu, X.M.; Zhao, S.Q.; Li, S.L.; Wang, J. An in vivo anti-tumor effect of eckol from marine brown algae by improving the immune response. Food Funct. 2019, 10, 4361-4371. [CrossRef]

132. Kong, C.S.; Kim, J.A.; Yoon, N.Y.; Kim, S.K. Induction of apoptosis by phloroglucinol derivative from Ecklonia cava in MCF-7 human breast cancer cells. Food Chem. Toxicol. 2009, 47, 1653-1658. [CrossRef]

133. Kang, M.H.; Kim, I.H.; Nam, T.J. Phloroglucinol induces apoptosis via apoptotic signaling pathways in HT-29 colon cancer cells. Oncol. Rep. 2014, 32, 1341-1346. [CrossRef]

134. Kang, M.H.; Kim, I.H.; Nam, T.J. Phloroglucinol induces apoptosis through the regulation of insulin-like growth factor 1 receptor signaling pathways in human colon cancer HT-29 cells. Int. J. Oncol. 2014, 45, 1036-1042. [CrossRef] 
135. Eo, H.J.; Kwon, T.H.; Park, G.H.; Song, H.M.; Lee, S.J.; Park, N.H.; Jeong, J.B. In Vitro Anticancer Activity of Phlorofucofuroeckol A via Upregulation of Activating Transcription Factor 3 against Human Colorectal Cancer Cells. Mar. Drugs 2016, 14, 69. [CrossRef]

136. Gonzalez-Avila, G.; Sommer, B.; Mendoza-Posada, D.A.; Ramos, C.; Garcia-Hernandez, A.A.; Falfan-Valencia, R. Matrix metalloproteinases participation in the metastatic process and their diagnostic and therapeutic applications in cancer. Crit. Rev. Oncol. Hematol. 2019, 137, 57-83. [CrossRef] [PubMed]

137. Byun, S.Y.; Ham, Y.M.; Jeong, D.J.; Kim, H.B.; Kim, J.H.; Song, Y.K.; Yoo, B.S. Ecklonia cava Extract with High Antioxidant Activity and Process for Preparing the Same Using Supercritical Carbon Dioxide Extraction. KR101217472B1, 2 January 2013.

138. Garcia, M.J.N.; Guerrero, M.S.; Torres, J.S. Antioxidant Extract from Brown Macroalgae and Method for Obtaining Same. US20160074317A1, 17 March 2016.

139. Choi, J.S.; Jung, H.Y.; Jung, J.H.; Kang, H.S.; Son, B.H. Composition Comprising Phlorotannins Isolated from the Extract of Ecklonia stolonifera Okamura Having Anti-Oxidative Activity. KR100512482B1, 5 September 2005.

140. Kim, M.M.; Kim, S.K.; Lee, S.H.; Yanping, Z. An Anti-Oxidant Active Composition Containing Compounds from Ishige okamurae. KR20100039104A, 15 April 2010.

141. Choi, J.S.; Kim, A.R.; Kim, H.R.; Kwon, M.S.; Shin, T.S.; Woo, H.C. Anti-Inflammatory Composition Containing Phlorotannins from Ecklonia stolonifera and Ecklonia cava Extract as an Effective Component. KR20110035127A, 6 April 2011.

142. Besnard, M.; Grandieu, P.; Inisan, C.; Lerat, Y.; Megard, D.; Mitjavila, M.T.; Rousseau, I.; Simonetti, P. Algae Extract Containing Polyphenols. EP1977756A1, 8 October 2008.

143. Kim, M.M.; Kim, S.K. Composition Containing Phlorotannin for Inhibition of Matrix Metalloproteinase Activities. KR100858847B1, 17 September 2008.

144. Hyun, J.W.; Hyun, K.H.; Kim, M.J.; Lee, N.H.; Lee, S.J. A Composition Containing Eckol for Inhibiting a Growth of Cancer Stem Cells. KR20120053265A, 23 September 2013.

145. Hyiun, J.W.; Kim, R.K.; Lee, S.J.; Yoon, C.H. An Anti-Cancer Composition Containing Eckol for Cancer Expressing k-Ras. KR101596989B1, 23 February 2016. 